\title{
Growth response of dental tissues to developmental stress in the domestic pig (Sus scrofa)
}

\begin{tabular}{|c|c|}
\hline Journal: & American Journal of Physical Anthropology \\
\hline Manuscript ID & AJPA-2018-00351.R1 \\
\hline Wiley - Manuscript type: & Research Article \\
\hline $\begin{array}{r}\text { Date Submitted by the } \\
\text { Author: }\end{array}$ & $\mathrm{n} / \mathrm{a}$ \\
\hline Complete List of Authors: & $\begin{array}{l}\text { Skinner, Mark; York University, Archaeology } \\
\text { Imbrasas, Mykolas ; University of Kent, School of Anthropology and } \\
\text { Conservation } \\
\text { Byra, Chris; Greenbelt Swine Veterinary Services Ltd, Technical Services } \\
\text { Veterinarian, BC Pork } \\
\text { Skinner, Matthew; University of Kent, Evolutionary Anthropology }\end{array}$ \\
\hline Key Words: & enamel, dentin, pathology, survivorship, osteological paradox \\
\hline $\begin{array}{r}\text { Subfield: Please select } 2 \\
\text { subfields. Select the main } \\
\text { subject first.: }\end{array}$ & Non-primate animal models, Bioarchaeology [including forensics] \\
\hline
\end{tabular}


Title: Growth response of dental tissues to developmental stress in the domestic pig (Sus scrofa)

Abbreviated title: dental tissues and stress in pigs

Authors: Mark F. Skinner ${ }^{1}$

Mykolas D. Imbrasas ${ }^{2}$

Chris Byra ${ }^{3}$

Matthew M. Skinner 2,4

1. Correspondence should be addressed to: mskinner@sfu.ca, +4407583

412295, Department of Archaeology, King's Manor, University of York, York, United Kingdom, Y01 7EP

2. School of Anthropology and Conservation

University of Kent

Marlowe Building

Canterbury, UK, CT2 7NR

3. Greenbelt Swine Veterinary Services Ltd., Technical Services Veterinarian, BC Pork, Chilliwack, BC, Canada

4. Department of Human Evolution

Max Planck Institute for Evolutionary Anthropology

Leipzig, Germany, 04103 


\begin{abstract}
Objectives: To compare relative response of enamel, dentin and bone to developmental stressors between attritional and catastrophic mortality assemblages of pigs.
\end{abstract}

Materials and Methods: Heads from 70 Sus scrofa of known sex, weight and age comprising an Attritional sample of 50 Sick Pen pigs that died prematurely vs. 20 Control pigs slaughtered at six months (Catastrophic assemblage). Hard tissue changes (alveolar bone thinning), abnormal bone formation (Harris lines) and remodeling (auditory bullae) were recorded. Areas and volumes of coronal enamel and dentin were recorded from microCT scans with Avizo 6.3 and Geomagic Wrap. Results: Attritional and Catastrophic assemblages are metrically indistinguishable. Ages at death and tissue measures in the Sick Pen (SP) pigs are differentially distributed, necessitating partition into developmental outcome cohorts. SP 'late death' pigs are of lesser physiological maturity than expected, free of disease, with large dental tissue dimensions, comparable to 'Controls'. SP 'early death' pigs have $5 \%$ less dentin and enamel and chronic bone infection. Older cohorts of the SP 'early deaths' mortality assemblage show progressively reduced enamel. SP pigs show dental evidence of reduced bone mass in the maxilla.

Discussion: Bone, dentin and enamel tissues, each, respond distinctively to developmental stressors. Bone mass evinces malnutrition not disease. Both dental tissue reduction and abnormal bone formation link to chronic infection. Paradoxically, reduced dentin mass signals lower survivorship while reduced enamel signals enhanced survivorship. Meaningful comparison of Attritional and 


\begin{abstract}
Catastrophic assemblages necessitates recognition of developmental outcome cohorts, stratified by age at death and physiological maturity, to reveal heterogeneity of survivorship, tissue measures and lesions.
\end{abstract}

Key words: enamel, dentin, pathology, survivorship, osteological paradox

\title{
Introduction
}

A generation of bioarchaeologists has grappled with the provoking article by Wood et al (1992) that expressed fundamental concerns with the meaning of hard tissue lesions in archaeological skeletons for reconstructing health in a once-living assemblage (DeWitte and Stojanowski 2015). The challenge of the osteological paradox, paraphrased simplistically as 'bad health makes for good skeletons' or equally- 'sick skeletons signal a healthy response', has been distilled to the realization that we need to link hard tissue lesions, convincingly, to survivorship (Temple and Goodman 2014). Doing so is indeed a challenge. However, the emergence of sophisticated and nuanced methods applied to archaeological assemblages suggest these difficulties can be overcome. For example, the linkage of famine-related deaths to paleo-pathological markers suggests that linear enamel hypoplasia signals heightened frailty while bone pathologies (e.g., cribra orbitalia) do not (Yaussy and DeWitte 2018). The authors conclude that not all skeletal or dental lesions are equally sensitive or reliable gauges of frailty.

Skeletal and dental lesions reflect the response of the individual to stressors. Stress, per se, is not directly measurable in hard tissues (Hillson 2017). Most developmental hard tissue defects are non-specific "generalized" responses to any 
number and variety of stressors (Goodman and Rose 1990); consequently, use of the term 'stress' is often simply a frank acknowledgment of ignorance as to etiology. Consequently, we define stress simply as physiological disruption (Temple and Goodman 2014) sufficient to affect hard tissue formation.

In our view, in the absence of any ability to measure actual reproductive success in skeletal samples of individuals, the best measure of biological fitness is staying alive. The growing organism, faced with developmental stressors is, in effect, faced with the decision of whether to grow or conserve. Naturally, there are consequences for the individual.

“...humans differentially allocate energy budgets to essential tissue growth and maintenance during periods of stress. However, the process is not without consequence as these energetic allocations reduce investment in future growth and maintenance as well as other functions such as reproduction and disease resistance... These individuals are frequently stunted in size, reach reproductive maturity at earlier ages and die younger"(Temple and Goodman 2014) (p. 189).

In this study, we examine the link between survivorship and developmental stress early in life using two cohorts of domestic pigs (Sus scrofa) whose ages at death are known and whose cranio-dental features preserve a record of a variety of developmental stressors (some of which overlapped in time with dental crown formation). The first cohort is those that died prematurely (hereafter referred to as Sick Pen (SP) pigs, and are thus considered to have experienced developmental stress. The second cohort is a Control group that survived until normal slaughter age. We determine whether pigs with more, or more severe, lesions die at younger ages and whether their hard tissues (bone, enamel and dentin mass) are metrically affected in ways consistent with survivorship (Temple and Goodman 2014). Here 
we will use the phrases 'tissue volume' and 'tissue mass' interchangeably. Firstly, we will briefly review studies of the effect of environmental stressors on tooth size as well as the challenge of the osteological paradox.

Dental tissue volumes and developmental stressors

As estimates of the heritability of tooth size have reduced over the years, the potential of dental tissues to reflect environmental influence has correspondingly increased. Tooth size has long been an important subject of study in dentistry and anthropology. Orthodontists require knowledge of the predictability of tooth size (Osborne et al. 1958; Townsend and Brown 1978; Kabban et al. 2001) while anthropologists use tooth size for phylogenetic reconstructions and biological distance analysis (Pilloud and Kenyhercz 2016). However, over the past half century, estimates of the genetic contribution to tooth size have dropped from 0.9 (Garn et al. 1965) to roughly 0.64 (Osborne et al. 1958; Townsend and Brown 1978; Townsend et al. 2009). Environmental effects are now thought to account for about one-third of variation in tooth size; thereby providing a metrical means of studying the impact of social, nutritional and medical factors as these vary among human populations over space and time.

There are numerous studies of the effect of mal-, under and improved nutrition on tooth size in humans and animals (Shaw and Griffiths 1963; Keene 1971; DiOrio et al. 1973; Guagliardo 1982; Harris et al. 2001). In such studies, dental crowns are usually treated as homogenous structures (Potter et al. 1968; Kabban et al. 2001), with no concern for potential differences in tissue response to developmental stress, even though enamel and dentin develop from different germ 
layers over contrasting periods of time (Osborn 1981). This perspective may derive from studies such as Holloway et al.'s containing the assertion that smaller molars in the offspring of mother rats fed a 'low protein: high sucrose' diet, nevertheless, showed no difference in enamel thickness (1961). However, the plentiful literature on enamel thinning, arising from studies of enamel hypoplasia, (Boyde 1970; ElNajjar et al. 1978; Goodman and Armelagos 1985; Suckling et al. 1986; Goodman and Armelagos 1988; Goodman and Rose 1990; Goodman et al. 1991; Skinner and Goodman 1992; Eckhardt and Protch von Zieten 1993; Blakey et al. 1994; Ensor and Irish 1995; Duray 1996; Guatelli-Steinberg 1998; Goodman and Song 1999; Lukacs et al. 2001; King et al. 2002; Chollet and Teaford 2010; Guatelli-Steinberg et al. 2012; McGrath et al. 2015; Hillson 2017) suggests that the comparative response of enamel to stress should be re-evaluated. For example, a decrease in porcine enamel thickness in the area of 'depression' enamel defects has been reported (Witzel et al. 2008). Also, enamel thickness is an oft-recognized character in hominine systematics and dietary reconstructions (Martin 1985; Grine and Martin 1988; Olejniczak et al. 2008; Smith et al. 2012; Skinner et al. 2015). Similarly, a decrease in dentin volume, producing 'coronal waisting' has been linked to nutritional stress in chimpanzee infants (Skinner et al. 2012). Consequently, the potential for enamel and dentin to respond sensitively and independently to stressors needs to be assessed.

Our earlier study, related to this one, found that sick pigs exhibit thinning and fenestration of the molar tooth crypt wall associated with enamel defects (Skinner et al. 2014). Inherent in this conclusion is the assumption that tooth 
formation is less sensitive to developmental stress than is bone formation. The current study, using the same cohort of animals, asks whether dentin and enamel, also, differ in their response to stress.

A consideration of attritional and catastrophic assemblages

The living population may be the phenomenon of interest but is preserved only rarely, due to catastrophic events such as flash floods, war, or massacre that preserve all individuals (Wilson 1988; Margerison and Knusel 2002). A catastrophic assemblage is created by an event in which all individuals of a living assemblage die (and are preserved) without reference to host characteristics such as age, sex and frailty. For example, comparison of two catastrophic assemblages of culled elephants with an attritonal assemblage of drought driven die-off of elephants, near a dwindling water source, acknowledged that all three populations, sampled in death, likely differed (Conybeare and Haynes 1984). Specifically, one should expect to observe sub-groups within an attritional assemblage, which reflect heterogeneity of thanatic factors or time. The goal of this study is to record and understand heterogeneity of an attritional assemblage so as to allow meaningful comparison with a catastrophic assemblage.

A notable study of the difference between those that die and those that survive was made long ago by Bumpus in his study of sparrows exposed to a snow, rain and sleet storm: “...the former (survivors) are shorter and weigh less (i.e., are of smaller body), they have longer wing bones, longer legs, longer sternums and greater brain capacity" (Bumpus 1898)(p.213). Later re-analysis reported a bimodal distribution of measures among non-surviving females (Johnston et al. 1972). 
While Bumpus' influential study is noted as an early recognition of stabilizing selection, more importantly for our purposes, the death assemblage he described reflects heterogeneity of host vulnerability. In addition to variation in host vulnerability, an attritional assemblage is composed of individuals who differ from the living assemblage in exposure and response to stressors over time. Not surprisingly, an attritional assemblage may misrepresent the live population (Conybeare and Haynes 1984).

This study compares dental tissue volumes in two assemblages: a) pigs that died while in a sick pen; versus b) slaughter age (ca. 6 months) pigs that were sufficiently heavy (about $109 \mathrm{~kg}$ ) and healthy to go to slaughter. We consider these to be Attritional and Catastrophic assemblages, respectively. The Sick Pen pigs form a mortality cohort whose deaths occurred at any time between about three and seven months of age. Causes of death are not known but can be assumed to be of several kinds (McGee and Martin 1995); that is, there is heterogeneity of stressors (not mutually exclusive) some of which may have been chronic while others were acute, leading to immediate death. Consequently it would be simplistic to treat the Sick Pen sample as a homogenous entity. For the Catastrophic sample, cause of death is a known, single event - not several. Any negative events they had experienced earlier, including, perhaps, time in the Sick Pen, were insufficient to cause them to die.

The objectives of this study are: a) to measure relative response of forming tissue types (bone, enamel, dentin) to developmental stressors, within and between cohorts of sick pen (SP) and Control (Control) domestic pigs (Sus scrofa); b) examine 
whether there is link between tissue mass and survivorship; and c) to evaluate etiological influences on reduction of tissue mass.

\section{(Table 1 about here)}

\section{Materials and Methods}

The sample of pigs used in this study (Table 1) has been reported in detail previously (Skinner et al. 2014). . No animals were subject to experimental procedures; nor were their deaths linked to this research. All animals died or were slaughtered as part of the normal operations of hog production independent of the conception or conduct of this research.

Briefly, pigs were obtained from a hog supplier in the Fraser River valley of British Columbia, Canada. The heads of 50 successive natural fatalities (termed Sick Pen pigs) were procured, deep frozen, and de-fleshed for comparison with 20 pigs, from the same source, which survived to slaughter age (termed Control pigs). All animals were exposed to the same husbandry practices (Supplementary Materials). Weight and age at death of the mortality cohort animals were recorded. No records were kept of which were littermates, nor of size at birth. None was likely to have been a runt (Widdowson 1971) since newly-born pigs with birth weights of less than approximately one kg are not kept Heterogeneity in the Sick Pen assemblage: Developmental Outcomes Marked variation in developmental fate of these animals necessitated the creation of mortality sub-groups in order to make meaningful comparisons of dental measures both within and between the attritional and catastrophic assemblages (Fig. 1). 
Figure 2 illustrates the relationship of weight and age at death or slaughter age for our sample in comparison to the Garth Standards (Carr 1998). Some SP pigs (green squares in Figure 2) failed to reach a minimum weight (85 kg) sufficient for slaughter despite remaining in the Sick Pen for weeks and months beyond normal slaughter age (ca. 6 months) presumably because of permanent damage to vital tissues. These pigs are classified as Sick Pen 'late deaths'. Such animals may have been switched into and out of the Sick Pen more than once in the hopes they would grow sufficiently for slaughter.

The remaining Sick Pen pigs died prior to normal slaughter age, anywhere between 0.22 to 0.43 years. These pigs are classified as Sick Pen 'early deaths'. Sick Pen 'early death' pigs were further subdivided into four groups based on age and physiological maturity. The latter evaluation is based on the averaged rank position of each pig in terms of three seriated physiological variables: dental formation (from radiographs), skull length, and weight at death (acknowledging that the last measure may have changed dramatically in the days leading up to death). We term this an overall Developmental Rank. The four groups are created from a simple dichotomization of age at death (above and below median age) and Developmental Rank (above and below mid-rank). These groups are deemed to reflect decreasing 'felt stress' and ordered as follows: low age/low rank (SP 1); low age/high rank (SP 2); high age/low rank (SP 3); high age/high rank (SP 4). These are conceptualized as 'developmental outcomes'; they are used as analytical units to test for heterogeneity within the Attritional assemblage.

\section{Dental measures}


Dental formation for the maxillary and mandibular cheek teeth was recorded radiographically with a Fisher Portable 200 x-ray machine using standard procedures. Simple measures of the cranium, as well as mesio-distal length and bucco-lingual width for the third and fourth deciduous molars, were taken with Mitutoyo digital calipers. Mandibular first molar (usually left) tissue volumes were measured from microCT scans (Diondo, $130 \mathrm{kV}, 130 \mathrm{~mA}, 0.5 \mathrm{~mm}$ brass filter, 3060 projections, 2 frame averaging, isometric voxel resolution of 20-25 microns).

Reconstructed TIFF image stacks of each first molar tooth were filtered with a macro that utilizes a three-dimensional median and a mean of least variance filters with a kernel size of 1 to 3 (Wollny et al. 2013). Filtering facilitates the manual segmentation of dental tissues and improves tissue grey-scale homogeneity, while preserving the morphology of dental structures. The filtered image stacks were imported into Avizo 6.3 and segmented semi-automatically, after which enamel volumes for each tooth were calculated from the segmentation.

Because cracks may display the same greyscale values as dentin, the enameldentin junction was extracted as a triangulated surface file (PLY format) and processed in Geomagic Wrap to remove any surface triangles that represent cracks; after which surface area measurements of the models were taken. Dentin volume was measured in Geomagic Wrap by sealing the bottom of each EDJ surface model with a consideration for the shape of the cervix.

In this study we evaluate the metrics of two dental tissues: enamel and dentin. Their apposition starts at the EDJ proceeding in opposite directions. Dentin volume is closely related to the size of the EDJ while enamel thickness is a function 


\author{
of the amount and duration of secretion by ameloblasts. These may be considered as \\ two independent heterochronological processes (Kono 2004). In that we judge \\ volume measures to be more generally more informative of cellular function than \\ are more traditional linear variables, we created four direct measures and four \\ indirect measures; as follows; \\ $\underline{\text { Primary variables }}$
}

Enamel cap volume $\left(\mathrm{mm}^{3}\right)$ : tissue segmented digitally above the enameldentin junction

Coronal dentin volume $\left(\mathrm{mm}^{3}\right)$ : pulp chamber is incorporated in this dimension

Enamel-dentin junction (EDJ) surface area $\left(\mathrm{mm}^{2}\right)$ : area of convoluted contact between enamel and dentin

Cervical area $\left(\mathrm{mm}^{2}\right)$ : horizontal plane at most cervical extent of enamel Derived variables

Enamel/dentin volume ratio: dimensionless index intended to detect relative sensitivity to stress of the two tissue types

Average enamel thickness $(\mathrm{mm})$ : volume $\div$ EDJ area

Average coronal dentin thickness $(\mathrm{mm})$ : volume $\div$ EDJ area

EDJ area $\div$ cervical area: dimensionless index intended to detect cervical constriction, if any, arising between birth and crown completion (ca. 3 months).

Radiography: 
In addition to assessing tooth formation, radiographs were taken of mandibular rami to evaluate disturbed bone growth (Harris lines and radiolucencies) and of fractured cranio-facial bones (Skinner et al. 2014).

\section{Enamel wear:}

We expect Sick Pen pigs to have reduced dental tissues and reduced survivorship. In our study, enamel wear is a confounding variable in that longer-lived animals can be expected to have more worn teeth. If, despite this likelihood, it can be shown that reduced survivorship is significantly linked to reduced tissue mass, then the finding is strengthened; in other words the study design is conservative. Including animals with worn teeth increases the probability of Type II error (failing to detect a real difference), a disadvantage offset by an increase in statistical power. Enamel wear is recorded as none; trace faceting (indicating gingival eruption) and dentin exposure on one or more cups, visible in microCT images, indicating the progressive attainment of occlusal eruption. Most of the Control and Sick Pen 'late deaths' were sufficiently old that their first molars showed some (albeit slight) dentin exposure. Predictions and statistical analysis:

Markers of developmental stress are recorded in Table 1. We have no a priori reason to expect enamel and dentin to differ quantitatively in response to stress. We predict that tissue volumes will be greatest on average in Control pigs and least in the lowest age at death/lowest developmental rank cohort among the Sick Pen pigs. However, in that crown formation is completed prior to death in our sample, there will possibly be some individuals in the Attritional assemblage who had experienced little or no developmental stress during crown formation but who died suddenly. 
Specifically, we ask whether dental tissue volumes (enamel and dentin), created in the first three months of a pig's life are linked to survivorship in the succeeding months. If the answer is 'no', tissue volumes will not differ among developmental outcome cohorts in the Attritional assemblage nor in comparison of the latter to the Control/slaughter-age pigs. If yes, tissue volumes will differ significantly between early and later deaths in the Attritional assemblage; and we can ask in what direction (increase or decrease) do the volumes change.

Evaluation of differences among the developmental outcome groups was performed with the non-parametric median test, which tests whether the groups are sampled from a population in which the median of the test variable is the same. The alternative, Kruskal-Wallis test is sensitive to outliers and less suitable for our data. Alpha was set at 0.05 . Strictly speaking, in that we do not consider it biologically realistic to expect developmental stress to increase dental tissue volumes, we could have used one-tailed tests of significance, since our prediction is that the mortality cohort will have lessened tissue volumes; however, we felt it would be more conservative to use two-tailed tests.

\section{Results}

Figure 3 shows the relationship of age at death to Developmental Rank and illustrates the distribution of SP 'early death' cohorts (weight and physiological maturation are not recorded for individual Control pigs). As may be seen, Sick Pen 'late deaths', despite being markedly older, have physiological ranks noticeably less than expected in comparison to the trend for the Sick Pen 'early death' pigs; in other 
words, as a group, 'late death' pigs are dentally immature, small-headed, and/or light-weight.

\section{Comparative development at birth}

While weights were not recorded for these animals at birth we do have tooth dimensions for teeth formed prenatally and those formed both prenatally and postnatally (Skinner et al. 2014) which are not part of this particular study of lower first molars whose crown formation is almost entirely (ca. 90\%) postnatal (based on location of the neonatal line visible in a thin section). Table 2 compares dental areas for deciduous lower third molars (prenatal) and deciduous upper fourth molars (both). It can be concluded that the Sick Pen and Control pigs start out with similar tooth sizes at birth but later-forming teeth come to differ postnatally.

\section{(Table 2 about here)}

Sex differences

There are equal numbers of males and females in the Control sample while 20 of our 50 Sick Pen pigs are males. The distribution of sexes between the two Groups (Table 3) does not differ significantly (Pearson's Chi Square=0.583, Fisher's Exact Test $\mathrm{P}=0.594)$.

Mann-Whitney tests indicated no sex differences in dental volumes and areas in the sample as a whole or among the separate groups (similar results were obtained with parametric tests). Consequently, later analyses lump the sexes.

\section{(Table 3 about here)}

Comparison of assemblages 


\begin{abstract}
A simple comparison of the two assemblages shows only one statistically significant difference; that being the derived variable of average dentin thickness (Table 4). Simply put, with only one exception, the Attritional and Catastrophic assemblages are statistically indistinguishable. However, it is noteworthy that in every primary measure, the Sick Pen tissues are smaller and more variable than are those of the Controls. These observations suggest there may be masked heterogeneity in the Sick Pen assemblage.
\end{abstract}

\title{
(Table 4 about here)
}

\section{Heterogeneity within Sick Pen assemblage}

Tissues masses are compared among the Sick Pen 'early deaths', 'late deaths' and Controls (Table 5). The 'late deaths' cohort has the largest tissue masses and the 'early deaths' group of cohorts, the smallest; Controls have middling values. Given this situation, it is appropriate to ask whether the Sick Pen ' early deaths' are statistically distinguishable from either of the other cohorts.

\section{(Table 5 about here)}

In a comparison within the Sick Pen assemblage, statistically significant differences in dental measure (ca. 12\%) are observed between the 'early' and 'late death' groups in dentin volume and area of the cervix (Table 5). Interestingly, the ratio of enamel volume to dentin volume is higher in the SP 'early deaths'. Clearly, all three variables reflect coronal dentin space, which is reduced in those pigs that died before slaughter age.

In a comparison between the 'SP early deaths' and 'Control' pigs (i.e., excluding the 'late death' cohort), the former group of cohorts show significantly 
reduced (ca. 5\%) dentin volume and average dentin thickness and, consistently, heightened ratio of enamel to dentin volume (Table 5); again, all are attributable to reduced coronal dentin in the Attritional mortality cohorts.

Evaluation of enamel volume and related variables is problematic due to small samples, occasioned by enamel wear in the 'late deaths' cohort. The Sick Pen 'early deaths' show a statistically non-significant reduction in enamel of about 5\% compared to the other groups.

Comparison of developmental outcome cohorts

A finer-grained analysis of median values of tissue masses among developmental outcome cohorts indicates that, with the exception of coronal dentin mass, median values of all primary and secondary variable measures vary significantly among cohorts (Table 6). A graphical depiction of these results is shown in Figures 5 thru 12. In terms of the primary variables, enamel cap volume (Fig. 5) and EDJ surface area (Fig. 7) decline with survivorship among the 'early deaths' and contrast with the 'late death' Sick Pen pigs ( $\mathrm{P}=0.038$ and 0.024 , respectively). Volume of coronal dentin does not vary significantly among developmental cohorts $(\mathrm{P}=0.297)$ but is greatest in the SP 'late deaths' (Fig. 6). Area of the cervix (Fig. 8) is significantly smaller in the SP 'early deaths' compared to the 'late deaths' $(\mathrm{P}=0.048)$. The derived variables confirm these impressions, with the relative proportion of enamel to dentin (Fig. 9) and average enamel thickness (Fig. 10) declining with age at death among the 'early deaths' ( $\mathrm{P}=0.0004$ and 0.028 , respectively). Interestingly, average dentin thickness (Fig. 11) increases significantly among developmental cohorts ranged from 'worst' to 'best' outcome $(\mathrm{P}=0.004)$; a result which can come about 
from reducing EDJ area and/or increasing dentin volume. Cervical constriction (Fig. $12)$ is most marked in the two low age Sick Pen cohorts $(\mathrm{P}=0.043)$. Finally and notably, median values of tissue measures in 'late death' pigs exceed those of the Control pigs for all primary variables. In conclusion, analysis by developmental cohorts reveals marked heterogeneity of both enamel and dentin tissue mass measurements among developmental outcome cohorts.

\section{(Table 6 about here)}

\section{Survivorship}

The Control pigs were all slaughtered at about the same stage of development. Consequently the following analysis compares tissue masses and age at death among developmental outcome cohorts excluding Controls whose individual age at death are not known. The bottom panel of each of Figures 5 thru 12 shows the relationship. For most variables the tissue measure changes with age at death in the Sick Pen 'early deaths' while the 'late deaths' cohort's position is offset and clearly does not continue the former group's trend.

The most striking contrast in the analysis of all six cohorts together, described above, is the behavior of the enamel versus dentin tissues. Enamel volume is least in the longest surviving Sick Pen 'early deaths' cohort while measures of dentin mass either remain constant (volume) or increase (cervix area) in the longerlived assemblages. The derived measures remain consistent with the pattern shown by the primary variables. These impressions-that the Sick Pen 'early deaths' cohorts as a group show heterogeneity-are examined next.

Heterogeneity within the Sick Pen 'early deaths' grouping 
This grouping is the largest $(n \leq 42)$ and has the greatest potential for providing insights into the response of dental tissues to stress. However, when broken down into four separate cohorts the samples are small and the patterns need to be scrutinized for consistency (Table 7).

\section{(Table 7 about here)}

Fundamentally, enamel measures (including EDJ surface area) decline with increased survivorship while dentin measures remain fairly constant or increase non-significantly. These trends are shown most clearly by the reduction of enamel to dentin volume ratio (Fig. 9). Average dentin thickness increases with survivorship, which seems to be driven by the marked (but not statistically significant) reduction in EDJ surface area with increased age at death (Fig. 7).

The decline of enamel measures with increased survivorship holds even in pigs with no wear at all. There is a decline in enamel volume ranging between 10 and $16 \%$ compared among wear groups (Fig. 13).

\section{Bone mass and developmental outcome}

We assess bone mass through a reconsideration of 'crypt fenestration', previously reported (Skinner et al. 2014), occurring over the forming last molar crypt area of the pig maxilla among these pigs. The Sick Pen assemblage showed $82 \%$ with bone thinning (crypt fenestrations) compared to 55\% in the Controls. In a cross-tabs analysis, equal proportions (roughly 85\%) of both SP 'early" and 'late deaths' show crypt fenestrations (Chi square $=0.087, \mathrm{P}=0.768$ ). Similarly, crypt fenestrations are evenly distributed among the four cohorts comprising the SP 'early deaths' (Chi square $=4.987, \mathrm{P}=0.173$ ). It can be concluded that bone thinning is more common in 
the Sick Pen assemblage as a whole but otherwise does not vary with developmental outcome. Bone thinning is common to Sick Pen 'early' and 'late deaths' groups, both of which share a pattern of growth faltering (Fig. 2).

Summary of results on hard tissue analysis

1. In terms of measures of both enamel and dentin, Controls are virtually indistinguishable from the SP mortality assemblage due to marked heterogeneity among developmental outcome cohorts. Sick Pen 'late deaths', which as a group lived beyond customary slaughter age, show significantly larger dentin-related measures in comparison to both 'early deaths' and Controls.

2. In terms of the relationship of dental measures to survivorship, SP 'early deaths' show significantly declining enamel volume and, not surprisingly, decreasing enamel to dentin volume ratio. Both enamel and dentin thicknesses increase significantly with age at death, which can be attributed to the non-statistically significant reducing EDJ surface area. EDJ surface area as a variable behaves more like enamel than it does like dentin. This makes sense since enamel extension dictates in part the size of the EDJ.

3. Maxillary bone mass in the last molar crypt area is more reduced in the Sick Pen mortality assemblage than in the Control pigs.

\section{Etiological influences on tissue mass}

Given the observed patterns of metrical change or stasis in tissue measures, we turn now to a consideration of probable causes. We will examine growth attainment, bone formation and hard tissue lesions. All the Sick Pen pigs are light for their ages (Fig. 2). It can be assumed that growth faltering has occurred, as further attested by 
the evidence from crypt fenestrations. Although food quality and ration were tightly controlled for our sample, malnutrition might occur through social competition or, more likely in the case of husbanded pigs, through disease. For example, infection can produce malnutrition through diarrhea and anorexia, so clearly the two stressors are not mutually exclusive. However, some of the pigs show clear evidence of infection-particularly, inflamed and highly remodeled auditory bullae. In our experience, pigs affected with chronic middle ear infection thrive (somewhat), continue to eat, but are slow growers.

Our approach to elucidating etiology is to compare tissue volumes among three groups: those pigs with bone formation problems, those with infection (with or without problems of bone formation) and those with no evidence of hard tissue pathology. Table 1 lists a variety of hard tissue responses by the pigs to stressors. It is presumed that all the fractured facial bones (with two exceptions-pigs 5 and 9which have a well-healed zygomatic and coronoid process fracture, respectively) occurred after first molar crown formation was completed since the broken edges show little or no remodeling. All fractures are ignored for purposes of analyzing tissue mass. Similarly, there are a few instances of infection on crowns or roots that are clearly post-eruptive in timing. These are excluded from the 'infected' sample in the following analyses of tissue mass. For analytical purposes here, we have chosen to divide the pigs into the following non-mutually exclusive categories (Table 8):

a) Pigs with no hard tissue lesions

b) Bone formation lesions; i.e., mandibular ramus abnormalities such as Harris lines and radiolucent borders (Skinner et al. 2014) (excluding 
facial fractures). Pigs with abnormal rami plus infection are placed in the next grouping.

c) Pigs with well-established hard and soft tissue changes judged to be due to infection (with or without problems of bone formation) (including remodeled auditory bullae, bone plaques, eroded TMJ, dental and soft tissue abscesses).

\section{(Tables 8 and 9 about here)}

It can be seen in Table 8, which describes tissue measures for all three groups, that the presence of infection only significantly reduces dentin volume and EDJ surface area. A simple dichotomization of the sample into uninfected versus infected animals shows that the presence of infection is associated, in addition, with a reduction in area of the cervix (Table 9).

The reduction in enamel cap volume of about $11 \%$ in the animals with chronic infection is not quite statistically significant (two-tailed $\mathrm{P}=0.091$ ). The inclusion of pigs with worn enamel on their first molars increases sample size to the point where the ratio of median enamel mass in infected to uninfected pigs parallels that for dentin (Fig. 14). As noted earlier, the comparability of enamel volume ratios in unworn and worn teeth, boils down to whether infected animals have more worn teeth than they should. Average wear score (number of affected cusps, ranging from 0 to 4 ) is 1.9 in non-infected animals and 1.4 in infected animals, i.e., infected animals had less worn teeth than the uninfected animals. This implies that, if anything, inclusion of worn teeth would act to reduce enamel cap volumes more in the non-infected animals. Thus, the result-that infected animals showed smaller 
enamel caps and dentin measures-is believable. We conclude that a marked biological significance is being signaled in which infection is the likely cause of differences in tissue mass.

Disease, bone formation, and survivorship

We turn now to a consideration of whether animals with hard tissue lesions (diseased) show also reduced bone mass. We test this notion through examination of animals, with and without infection, who showed crypt fenestration (bone) and crypt fenestration enamel defects (CFEDs-dental hypoplasia due to crypt fenestration (Skinner et al. 2016)). Crypt fenestrations, reflecting bone thinning, are observed in $75 \%$ (9/12) of infected pigs and 76\% (44/58) of uninfected pigs while CFEDs are found in 75\% (9/12) of infected pigs and 84\% (49/58) of uninfected pigs. The differences are not statistically significant (data not shown). An examination of those pigs with diseased auditory bullae (see below) shows that the two pigs with most severely affected bullae do not show crypt fenestrations, further negating the view that bone mass is affected by chronic disease in these pigs. By sharp contrast, abnormal bone formation (as shown by Harris lines and radiolucencies in the mandibular rami) is seen in $66 \%$ (38/58) of uninfected animals but $92 \%$ of infected animals (Likelihood ratio=3.911, $\mathrm{P}=0.048$ ). In this case, disease is linked to abnormal bone growth.

Well-established bone infection takes several forms in these pigs but inflamed auditory bullae are the most striking (Fig. 15). Severity of the latter was judged on the basis of number and size of foramina, cloacae, swelling, shell-like formation, and bi-laterality. The relationship between age at death and dental 
tissues (ratio of enamel to dentin) as well as severity of affected bullae is shown in Fig. 16. As survivorship increases, the relative amount of enamel decreases and the severity of disease declines. It seems likely that disease is a contributor to earlier death and enamel thinning. The likely agents for infection of the auditory bullae are oral/aural bacteria (Olson 1981).

While, as seen, bone mass does not seem to link to disease, bone formation does. Likewise, diseased animals show a reduction in enamel and dentin of about 11 and 9\%, respectively (Table 9, Fig. 14).

\section{Discussion}

We acknowledge that our sample sizes, especially for sub-divided mortality cohorts, are small. We had not anticipated the observed complexity of tissue responses to stress and, hence our interpretations are cautious. Nevertheless, the general approach of drawing upon readily-available domestic farm animals, whose individual development is closely monitored by cost-conscious producers, we would argue is an almost untapped resource to address theoretical issues in skeletal biology (Skinner 2017). The observed tissue reductions noted above are small in absolute terms but in relative terms (ca. 10\%) are comparatively quite large; e.g., permanent stature reduction resulting from the notoriously severe 'Dutch famine' amounted to about 2\% (Portrait et al. 2017).

Here we will revert to using the terms 'Attritional' and 'Catastrophic' as one of our primary goals in this research was to see if dental tissue masses differed between a natural mortality cohort and a living assemblage that had died 
catastrophically. At the outset of this study, our expectation was that pigs, which had experienced sufficient developmental stress to kill them, would show reduced tissue volumes. In a crude comparison of the two assemblages (Sick Pen and Control pigs), this is not true. Fundamentally, in explanation of this finding, the Sick Pen assemblage is markedly heterogeneous both in terms of age at death and in measurements of dental tissues. Those Sick Pen pigs who lingered past customary slaughter age (so-called 'late deaths') had large coronal dentin volume exceeding that of Control pigs. Enamel measures did not differ among the three groups.

However, with the analytical creation of six developmental cohorts based on the combination of age at death and physiological maturation, it became clear that, counter-intuitively, enamel volume declined with increasing survivorship among the four Sick Pen 'early death' cohorts. We will return to this anomaly shortly. Dentin showed no such pattern. Estimation of bone mass from crypt fenestration indicates that crypt wall thinning is more common in the mortality cohort but does not vary within this assemblage. It can be seen that each of the three tissue types (enamel, dentin, bone) responds differently to developmental stress.

In the hope of understanding these contrasts, recourse was made to disease history. Chronic disease, as exemplified most dramatically by florid remodeling of auditory bullae, is assumed here to have prevailed during dental crown tissue and bone formation. Bone mass is not linked to disease in this study. However, the presence of disease links significantly with abnormal bone formation and a reduction of dental tissue volumes (enamel ca. 11\%, dentin ca. 9\%). More severe chronic infection is linked to a relative decrease in enamel volume and in 
survivorship. Significantly, neither the 'late deaths' nor Controls show infection of this nature.

The decline of enamel volume with increased survivorship among cohorts within a mortality assemblage is unexpected and requires consideration. As noted in this study, enamel thinning is linked to chronic infection. A cardinal sign of inflammation is fever (Kreshover and Clough 1953) and a common explanation for enamel thinning in the form known as enamel hypoplasia is fever (El-Najjar et al. 1978). It would seem that enamel thinning is a positive sign (increased survivorship) but also signals the presence of disease. This conundrum can be resolved by recourse to the literature on whether fever is adaptive (Kluger 1986). This is considered an old dispute (Romanovsky and Szekely 1998) which has been largely resolved in the sense that fever is now considered an adaptive thermoregulatory response which, despite being metabolically costly, often leads to enhanced immune response, inhibition of a pathogen (Hart 1988) and which confers a survival benefit. Fever acts as a systemic alert system for surveillance of invading pathogens by enhancing the immune system (Elliot et al. 2002; Evans et al. 2015). The latter authors conclude that the survival benefit conferred on the host outweighs the metabolic cost of fever.

In terms of the response of enamel to fever, it has been shown experimentally, by injecting turpentine into rats in order to produce a fever, that it is the fever itself not the disease that produces enamel defects (Tung et al. 2006). Also enamel is more sensitive to fever than is dentin (Kreshover and Clough 1953; Ryynänen et al. 2014). The decline in relative proportion of enamel to dentine 
shown in Figure 16 conforms with experimental evidence that the ratio of enamel to dentin height in developing mouse molars reduces with duration of fever (Ryynänen et al. 2014).

Notably, older animals from the Attritional mortality and Catastrophic assemblages have no evidence of chronic infection. By inference 'early deaths' are linked to infection. In our study, infection is associated with reduced dental volumes. One would expect the thinnest enamel in the youngest deaths. This is not so. Longer-lived 'early death' pigs have thinner enamel. In that enamel formation is completed before death, their advantage arose during crown formation when combatting infection, presumably through the benefits of fever which, inadvertently, acted to reduced enamel.

One of the motives for undertaking this study was to assess whether enamel thickness could be used as a proxy for developmental well-being much as stature is used in human growth studies. Just as there are myriad factors that can affect growth in stature, ranging from genetics to malnutrition and disease, we hoped that enamel thickness could be a powerful summation of developmental experience. If so, we could draw upon insights taken from the literature of growth studies, commencing some two centuries ago, which has so enriched our understanding of human biology (Bogin 1999; King and Ulijaszek 1999) and guided our approaches to epidemiology (Steckel 1995). Our zeal has been tempered by the results of this study which suggest that in domestic pigs, subject to developmental stress, each oral hard tissue has a somewhat different story to tell. The presence of chronic disease, likely accompanied by bouts of fever, is a key factor. Simply put, abnormal bone 
formation and reduced dentin mass are linked to reduced survivorship while enamel reduction is linked to enhanced survivorship.

The other motive for this study was to determine if a domestic pig model could contribute to the important debate subsumed under the rubric 'osteological paradox' which we summarized earlier. We acknowledge that, whatever the findings of our research, we have to be cautious about generalizing the results to other species. Domestic pigs are selected and husbanded to gain weight extremely fast and efficiently. It is not likely that their tissue biology, diseases and relative survivorship can be applied directly to ancient humans.

In our study, we have the advantage of knowing, with precision, age at death which allows us to test for differentially distributed measures of dental tissues and to evaluate the role of chronic disease. It is very clear from our results that the Attritional assemblage is much worse off developmentally and in terms of survivorship than are the pigs that make it to slaughter. However, in terms of dental tissue measurements, the two groupings are indistinguishable, simply because the Attritional assemblage shows marked heterogeneity in survivorship (early and late death groups) with notably larger coronal dimensions in the latter cohort. In that the Control cohort shows intermediate tissue measures, this cohort may be a product of stabilizing selection.

While most of the Sick Pen 'early death' pigs show problems of size and hard tissue formation, a notable component (16\%) of the Attritional assemblage (the Sick Pen 'late deaths'), if we may generalize, have healthy-looking, large hard tissues, and survived longer but, nevertheless, still died. Whether such laggards are a typical 
component of most Attritional assemblages awaits confirmation. In sum, most of our 'early death' domestic pigs show compromised hard tissues, signaling real problems of survivorship. The 'late deaths' are developmentally retarded, healthy-looking and survived a little longer before becoming part of a mortality cohort. In pigs, avoidance of disease, or the ability to overcome infection, is key to longer survival. In terms of the 'osteological paradox', relatively lesion-free and large-toothed cohorts are found in both the Attritional and Catastrophic assemblages. Short-lived pigs, as a group, tend to show chronic infection, abnormal bone formation and reduced volumes of dentin and enamel. However, diminished enamel per se is clearly linked to enhanced survivorship among pigs inferred to have been experiencing fever.

\section{Conclusions}

All three oral hard tissues (bone, dentin and enamel) respond in their own characteristic way to developmental stressors. We can link clear signs of infection to dental tissue reduction and abnormal bone formation. Bone mass is evincing primarily malnutrition not disease. Both enamel and dentin are reduced (about $10 \%$ ) in response to long-standing disease during crown formation. Paradoxically, reduced dentin signals lower survivorship while reduced enamel signals enhanced survivorship. Extrapolating from pigs, we conclude that meaningful comparison of attritional and catastrophic assemblages necessitates the recognition of developmental outcome cohorts to reveal heterogeneity of survivorship, tissue measures and lesions. 


\section{Acknowledgements}

Joel Boardman made original observations and helped with photography of the infected auditory bullae. For CT scanning, we thank Jean Jacques Hublin, Heiko Temming and David Plotzki of the Department of Human Evolution, Max Planck Institute for Evolutionary Anthropology. 


\section{Literature cited}

Blakey ML, Leslie T, and Reidy JP. 1994. Frequency and chronological distribution of dental enamel hypoplasia in enslaved African Americans: A test of the weaning hypothesis. American Journal of Physical Anthropology 95:371-383.

Bogin B. 1999. Patterns of Human Growth. Cambridge: Cambridge University Press.

Boyde A. 1970. The surface of the enamel in human hypoplastic teeth. Archives of Oral Biology 15:897-898.

Bumpus HC. 1898. The elimination of the unfit as illustrated by the introduced sparrow, Passer domesticus. Biological lectures delivered at the Marine Biological Laboratory of Woods Hole 209-225.

Carr J. 1998. Garth Pig Stockmanship Standard. Sheffield: 5M Enterprise Limited.

Chollet MB, and Teaford MF. 2010. Ecological stress and linear enamel hypoplasia in Cebus. American Journal of Physical Anthropology 142:1-6.

Conybeare A, and Haynes G. 1984. Observations on elephant mortality and bones in water holes. Quatern Res 22:189-200.

DeWitte SN, and Stojanowski CM. 2015. The osteological paradox 20 years later: past perspectives, future directions. Journal of Archaeological Research 23:397-450.

DiOrio LP, Miller SA, and Navia JM. 1973. The separate effects of protein and calorie malnutrition on the development and growth of rat bones and teeth. The Journal of Nutrition 103:856-865.

Duray SM. 1996. Dental indicators of stress and reduced age at death in prehistoric Native Americans. American Journal of Physical Anthropology 99:275-286.

Eckhardt RB, and Protch von Zieten R. 1993. Enamel hypoplasia as indicators of developmental stress in pongids and hominids. Human Evolution 8:93-99.

El-Najjar MY, DeSanti MV, and Ozebek L. 1978. Prevalence and possible etiology of dental enamel hypoplasia. American Journal of Physical Anthropology 48(2):185-192.

Elliot SL, Blanford S, and Thomas MB. 2002. Host-pathogen interactions in a varying environment: temperature, behavioral fever and fitness. Proc R Soc Lond Ser B Biol Sci 269:1599-1607.

Ensor BE, and Irish JD. 1995. Hypoplastic area method for analyzing dental enamel hypoplasia. American Journal of Physical Anthropology 98:507-517.

Evans SS, Repasky EA, and Fisher DT. 2015. Fever and the thermal regulation of immunity: the immune system feels the heat. National Reviews of Immunology 15(6):335-349.

Garn SM, Lewis AB, and Keresky RS. 1965. Genetic, nutritional, and maturational correlates of dental development. J Dent Res 44:228-242.

Goodman AH, and Armelagos GJ. 1985. Factors affecting the distribution of enamel hypoplasias within the human permanent dentition. American Journal of Physical Anthropology 68:479-493.

Goodman AH, and Armelagos GJ. 1988. Clinical stress and decreased longevity in a prehistoric population. Amer Anthrop 90:936-944. 
Goodman AH, Martinez C, and Chavez A. 1991. Nutritional supplementation and the development of linear enamel hypoplasias in children from Tezonteopan, Mexico. American Journal of Clinical Nutrition 53:773-781.

Goodman AH, and Rose JC. 1990. Assessment of physiological perturbations from dental enamel hypoplasia and associated histological structures. Yearbook of Physical Anthropology 33:59-110.

Goodman AH, and Song R-J. 1999. Sources of variation in estimated ages at formation of linear enamel hypoplasias. In: Hoppa RD, and FitzGerald CM, editors. Human Growth in the Past: Studies from Bones and Teeth.

Cambridge: Cambridge University Press. p 210-240.

Grine FE, and Martin LB. 1988. Enamel thickness and development in Australopithecus and Paranthropus. In: Grine FE, editor. Evolutionary History of the 'Robust' Australopithecines. New York: Aldine de Gruyter. p 342.

Guagliardo MF. 1982. Tooth crown size differences between age groups: A possible new indicator of stress in skeletal samples. American Journal of Physical Anthropology 58:383-389.

Guatelli-Steinberg D. 1998. Prevalence and etiology of linear enamel hypoplasia in nonhuman primates. Eugene: University of Oregon.

Guatelli-Steinberg D, Ferrell RJ, and Spence J. 2012. Linear enamel hypoplasia as an indicator of physiological stress in great apes: Reviewing the evidence in light of enamel growth variation. American Journal of Physical Anthropology 148(2):191-204.

Harris EF, Potter RH, and Lin J. 2001. Secular trend in tooth size in urban Chinese assessed from two-generation family data. American Journal of Physical Anthropology 115:312-318.

Hart BL. 1988. Biological basis of the behavior of sick animals. Neurosci Biobehav Rev 12:123-137.

Hillson S. 2017. Enamel hypoplasia=stress? Stressed Out: Debunking the stress myth in the study of archaeological human remains. London: University College London Institute of Archaeology.

Holloway PJ, Shaw JH, and Sweeney EA. 1961. Effects of various sucrose: casein ratios in purified diets on the teeth and supporting structures of rats. Archives of Oral Biology 3:185-200.

Johnston RF, Niles DM, and Rohwer SA. 1972. Hermon Bumpus and natural selection in the house sparrow Passer domesticus. Evolution 26:20-31.

Kabban M, Fearne J, Jovanovski V, and Zou L. 2001. Tooth size and morphology in twins. Int J Paediatr Dent 11(5):333-339.

Keene HJ. 1971. Epidemiological study of tooth size variability in caries-free naval recruits. J Dent Res 50:1331-1345.

King S, and Ulijaszek SJ. 1999. Invisible insults during growth and development. In: Hoppa RD, and FitzGerald CM, editors. Human Growth in the Past: Studies from Bones and Teeth. Cambridge: Cambridge University Press. p 161-182.

King T, Hillson S, and Humphrey LT. 2002. A detailed study of enamel hypoplasia in a post-medieval adolescent of known age and sex. Archives of Oral Biology 47:29-39. 
Kluger MJ. 1986. Is fever beneficial? The Yale Journal of Biology and Medicine 9(1):89-95.

Kono RT. 2004. Molar enamel thickness and distribution patterns in extant great apes and humans: new insights based on a 3-dimensional whole crown perspective. Anthropol Sci 112:121-146.

Kreshover SJ, and Clough OW. 1953. Prenatal influences on tooth development: II Artificially induced fever in rats. J Dent Res 32:565-577.

Lukacs JR, Walimbe SR, and Floyd B. 2001. Epidemiology of enamel hypoplasia in deciduous teeth: explaining variation in prevalence in western India. Amer J Hum Biol 13: 788-807.

Margerison BJ, and Knusel CJ. 2002. Paleodemographic comparison of a catastrophic and an attritional assemblage. American Journal of Physical Anthropology 119:134-143.

Martin LB. 1985. Significance of enamel thickness in hominoid evolution. Nature 314:260-263.

McGee E, and Martin L. 1995. Chance and the taphonomy of the hominoid assemblage from the middle Miocene site at Pasalar, Turkey. Journal of Human Evolution 28:325-341.

McGrath K, Guatelli-Steinberg D, Arbenz-Smith K, Reid DJ, Cranfield MR, Stoinski TS, Mudakikwa A, Bromage TG, and McFarlin SC. 2015. Linear enamel hypoplasia prevalence in wild Virunga mountain gorillas from Rwanda. American Journal of Physical Anthropology Annual Meeting Issue Supplement 60:221.

Olejniczak AJ, Smith TM, Feeney RNM, Macchiarelli R, Mazurier A, Bondoli L, Rosas A, Fortea J, de la Rasilla M, Garcia-Tabernero A, Radovcic J, Skinner MM, Toussaint M, and Hublin J-J. 2008. Dental tissue proportions and enamel thickness in Neandertal and modern human molars. Journal of Human Evolution 55:12-23.

Olson LD. 1981. Gross and microscopic lesions of middle and inner ear infections in swine. Am J Vet Res 42(8):1433-1440.

Osborn JW. 1981. Dental Tissues. In: Osborne JW, editor. Dental Anatomy and Embryology. Oxford: Blackwell. p 155-209.

Osborne RH, Horowitz SL, and De George FV. 1958. Genetic Variation in Tooth Dimensions: A Twin Study of the Permanent Anterior Teeth. Amer J Hum Genet 10(3):350-356.

Pilloud M, and Kenyhercz M. 2016. Dental Metrics in Biodistance Analysis. 135-155 p.

Portrait FRM, van Wingerden TF, and Deeg DJH. 2017. Early life undernutrition and adult height: The Dutch famine of 1944-45. Economics \& Human Biology 27:339-348.

Potter RH, Yu PL, Dahlberg AA, Merritt AD, and Conneally PM. 1968. Genetic studies of tooth size factors in Pima Indian families. Amer J Hum Genet 20(2):89-100.

Romanovsky AA, and Szekely M. 1998. Fever and hypothermia: two adaptive regulatory responses to systemic inflammation. Medical Hypotheses 50:219226. 
Ryynänen H, Sahlberg C, Lukinmaa P-L, and Alaluusua S. 2014. The effect of high temperature on the development of mouse dental enamel in vitro. Archives of Oral Biology 59(4):400-406.

Shaw JH, and Griffiths D. 1963. Dental abnormalities in rats attributable to protein deficiency during reproduction. J Nutr 80:123-141.

Skinner MF. 2017. Bad times-hard tissues: Not good, but better, science. Stressed out: Debunking the stress myth in the study of archaeological human remains. London: University College London Institute of Archaeology.

Skinner MF, and Goodman AH. 1992. Anthropological uses of developmental defects of enamel. In: Saunders SR, and Katzenberg A, editors. Skeletal Biology of Past Peoples: Research Methods. New York: Wiley-Liss. p 153-174.

Skinner MF, Rodrigues AT, and Byra C. 2014. Developing a pig model for crypt fenestration-induced localized hypoplastic enamel defects in humans. American Journal of Physical Anthropology 154:239-250.

Skinner MF, Skinner MM, and Boesch C. 2012. Developmental defects of the dental crown in chimpanzees of the Taï National Park, Côte D'Ivoire. Coronal waisting American Journal of Physical Anthropology 149:272-282.

Skinner MF, Skinner MM, Pilbrow VC, and Hannibal DL. 2016. An enigmatic hypoplastic defect of the maxillary lateral incisor in recent and fossil orangutans from Sumatra (Pongo abelii) and Borneo (Pongo pygmaeus). International Journal of Primatology 37:548-567.

Skinner MM, Alemseged Z, Gaunitz C, and Hublin J-J. 2015. Enamel thickness trends in Plio-Pleistocene hominin mandibular molars. Journal of Human Evolution 85:35-45.

Smith TM, Olejniczak AJ, Zermeno JP, Tafforeau P, Skinner MM, Hoffman A, Radovcic J, Toussaint M, Kruszynski R, Menter C, Moggi-Cecchi J, Glasmacher UA, Kullmer O, Schrenk F, Stringer C, and Hublin J-J. 2012. Variation in enamel thickness within the genus Homo. Journal of Human Evolution 62:395-411.

Steckel RH. 1995. Stature and the standard of living. J Econ Lit 33(4):1903-1940.

Suckling G, Elliott DC, and Thurley DC. 1986. Macroscopic appearance and associated histological changes in the enamel organ of hypoplastic lesions of sheep incisor teeth resulting from induced parasitism. Archives of Oral Biology 31:427-439.

Temple DH, and Goodman AH. 2014. Bioarchaeology has a "health" problem: Conceptualizing "stress" and "health" in bioarchaeological research. American Journal of Physical Anthropology 155:186-191.

Townsend G, Hughes T, Luciano M, Bockmann M, and Brook A. 2009. Genetic and environmental influences on human dental variation: a critical evaluation of studies involving twins. Arch Oral Biol 54 Suppl 1:S45-51.

Townsend GC, and Brown T. 1978. Heritability of permanent tooth size. Am J Phys Anthropol 49(4):497-504.

Tung K, Fujita H, Yamashita Y, and Takagi Y. 2006. Effect of turpentine-induced dever during the enamel formation of rat incisor. Archives of Oral Biology 51:464-470. 
Widdowson EM. 1971. Intra-Uterine Growth Retardation in the Pig. I. Organ Size and Cellular Development at Birth and after Growth to Maturity. Neonatology 19(4-6):329-340.

Wilson MVH. 1988. Taphonomic processes: Information loss and information gain. Geosci Can 15(2):131-148.

Witzel C, Kierdorf U, Schulz M, and Kierdorf H. 2008. Insights from the inside: Histological analysis of abnormal enamel microstructure associated with hypoplastic enamel defects in human teeth. American Journal of Physical Anthropology 136:400-414.

Wollny G, Kellman P, Ledesma-Carbayo M-J, Skinner MM, Hublin J-J, and Hierl T. 2013. MIA-a free and open source software for gray scale medical image analysis. Source Code Biol Med 8:20.

Wood JW, Milner GR, Harpending HC, and Weiss KM. 1992. The osteological paradox: Problems of inferring prehistoric health from skeletal samples. Curr Anthrop 33:343-370.

Yaussy SL, and DeWitte SN. 2018. Patterns of frailty in non-adults from medieval London. International Journal of Paleopathology 22:1-7. 
Table 1. Composition of sample separated by group (Control and Sick Pen) and sex, seriated by age at death with hard and soft tissue abnormalities indicated.

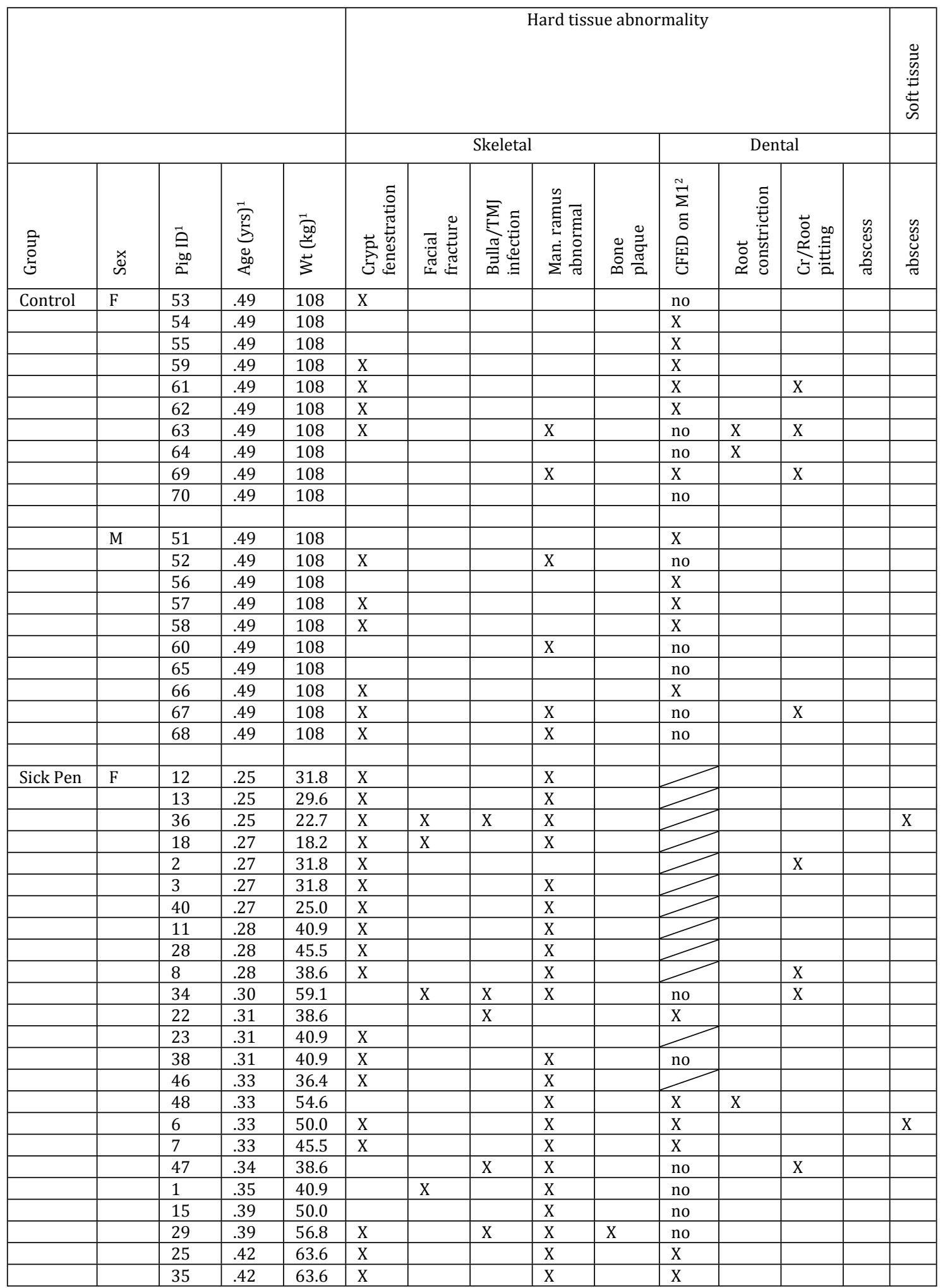




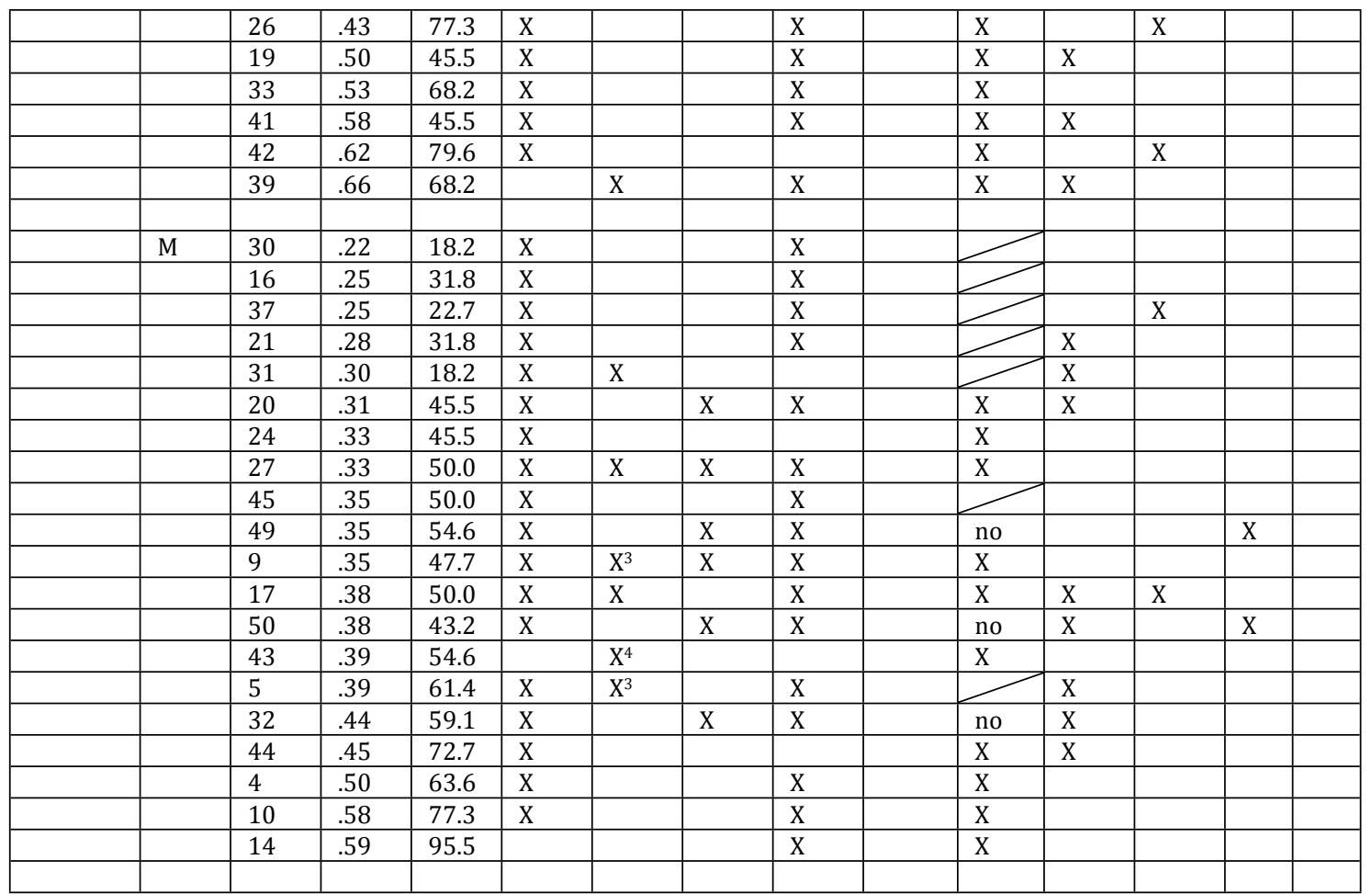

1. Ages at death and weight for Control pigs presumed to be normal age at slaughter weight

2. Crypt fenestration enamel defect (Skinner et al. 2014; Skinner et al. 2016)

3. Healing or healed fracture

4. Maggots in mouth 
Table 2. Deciduous molar tooth area $\left(\mathrm{mm}^{2}\right)$ for molars that form prenatally versus those that form both prenatally and postnatally compared between all Sick Pen pigs and Control pigs.

Group Tooth type $\underline{\mathrm{N}}$ DM3 area SD 't'-value Prob.

Sick Pen $\quad$ Lo DM3 $^{1} \quad 50 \quad 49.4 \quad 4.6 \quad-0.452 \quad 0.653$

Control $\quad 20 \quad 50.0 \quad 5.0$

$\begin{array}{llllll}\text { Sick Pen Up DM4 } & 49 & 140.0 & 13.3 & -2.773 & 0.007\end{array}$

$\begin{array}{llll}\text { Control } & 20 & 149.6 & 12.7\end{array}$

1. Lo=lower, Up=upper, $\mathrm{D}=$ deciduous, $\mathrm{M}=$ molar 
Table 3. Male and female unworn enamel and dentin volumes in lower first molars:

Sick Pen 'early death' pigs, Sick Pen 'late death' pigs and Control (there are no unworn male enamel crowns among the 'late deaths' group)

\begin{tabular}{|c|c|c|c|c|c|c|c|c|}
\hline \multirow{2}{*}{$\begin{array}{l}\text { Primary } \\
\text { measure }\end{array}$} & \multirow[t]{2}{*}{ Group } & \multirow[t]{2}{*}{$\underline{\text { Sex }}$} & \multirow[t]{2}{*}{$\underline{\mathrm{N}}$} & \multirow[t]{2}{*}{ Mean } & \multirow[t]{2}{*}{$\underline{S D}$} & \multirow[t]{2}{*}{ Median } & \multicolumn{2}{|c|}{ Mann-Whitney } \\
\hline & & & & & & & $\underline{Z}$ & $\underline{\text { Prob }}$ \\
\hline Enamel & \multirow[t]{4}{*}{ All } & Male & 8 & 313.9 & 55.1 & 297.3 & -0.722 & 0.470 \\
\hline Volume ${ }^{2}$ & & Female & 18 & 319.5 & 29.5 & 323.8 & & \\
\hline \multirow[t]{2}{*}{ EDJ area } & & Male & 30 & 422.4 & 46.2 & 423.8 & -0.332 & 0.740 \\
\hline & & Female & 40 & 424.2 & 32.4 & 424.3 & & \\
\hline \multirow{2}{*}{$\begin{array}{l}\text { Dentin } \\
\text { volume }\end{array}$} & & Male & 30 & 617.0 & 86.7 & 606.7 & -.166 & 0.868 \\
\hline & & Female & 40 & 615.0 & 59.1 & 612.6 & & \\
\hline \multirow{3}{*}{$\begin{array}{l}\text { Cervical } \\
\text { area }\end{array}$} & & Male & 28 & 138.3 & 15.2 & 135.1 & -1.148 & 0.251 \\
\hline & & Female & 38 & 141.9 & 11.3 & 140.9 & & \\
\hline & Cohorts & & & & & & & \\
\hline \multirow{6}{*}{$\begin{array}{l}\text { Enamel } \\
\text { volume }\end{array}$} & Sick Pen & Male & 8 & 313.9 & 55.1 & 297.3 & -0.722 & 0.470 \\
\hline & Early deaths & Female & 18 & 319.5 & 29.5 & 323.8 & & \\
\hline & & Male & 0 & & & & & \\
\hline & Late deaths & Female & 0 & & & & & \\
\hline & Control & Male & 0 & & & & & \\
\hline & & Female & 0 & & & & & \\
\hline \multirow[t]{6}{*}{ EDJ area } & SP & Male & 17 & 418.5 & 52.0 & 403.9 & -0.756 & 0.450 \\
\hline & Early deaths & Female & 25 & 420.7 & 31.2 & 418.7 & & \\
\hline & SP & Male & 3 & 436.7 & 37.5 & 432.7 & -0.447 & 0.655 \\
\hline & Late deaths & Female & 5 & 451.4 & 43.3 & 464.3 & & \\
\hline & Control & Male & 10 & 424.7 & 40.6 & 427.8 & -0.492 & 0.623 \\
\hline & & Female & 10 & 419.6 & 25.7 & 423.4 & & \\
\hline \multirow{6}{*}{$\begin{array}{l}\text { Dentin } \\
\text { volume }\end{array}$} & SP & Male & 17 & 583.5 & 73.6 & 571.7 & -1.294 & 0.196 \\
\hline & Early deaths & Female & 25 & 603.4 & 53.3 & 607.8 & & \\
\hline & SP & Male & 3 & 669.3 & 121.2 & 695.6 & -0.149 & 0.881 \\
\hline & Late deaths & Female & 5 & 662.4 & 75.3 & 679.3 & & \\
\hline & Control & Male & 10 & 658.2 & 80.0 & 661.5 & -1.134 & 0.257 \\
\hline & & Female & 10 & 620.5 & 58.2 & 606.4 & & \\
\hline \multirow{6}{*}{$\begin{array}{l}\text { Cervical } \\
\text { area }\end{array}$} & SP & Male & 15 & 133.2 & 14.9 & 134.2 & -1.389 & 0.165 \\
\hline & Early deaths & Female & 23 & 138.9 & 10.1 & 134.6 & & \\
\hline & SP & Male & 3 & 145.8 & 19.1 & 153.4 & -0.149 & 0.881 \\
\hline & Late deaths & Female & 5 & 151.8 & 10.6 & 152.2 & & \\
\hline & Control & Male & 10 & 143.7 & 12.9 & 142.8 & -0.076 & 0.940 \\
\hline & & Female & 10 & 143.7 & 12.0 & 142.1 & & \\
\hline
\end{tabular}

1. Parametric tests gave the same results as non-parametric tests

2. Enamel volumes are for molars with no wear 
Table 4. Comparison of dental tissue measures between assemblages

Measure $\begin{array}{llll}\underline{\text { Assemblage }} & & \underline{\text { Statistical test }} & \\ \underline{\text { Sick Pen }} \quad \underline{\mathrm{CV}} & \underline{\text { Control }} & \underline{\mathrm{CV}} & \underline{\mathrm{M}-\mathrm{W} \mathrm{Z}}\end{array}$

Enamel cap

volume

$\begin{array}{lll}\mathrm{n} & 50 & 20\end{array}$

10

Coronal dentin

volume

\begin{tabular}{|c|c|c|c|c|c|c|}
\hline & \multicolumn{4}{|c|}{ Assemblage } & \multicolumn{2}{|l|}{ Statistical test } \\
\hline & Sick Pen & $\mathrm{CV}$ & Control & $\underline{\mathrm{CV}}$ & M-W Z & Prob. \\
\hline $\mathrm{n}$ & 50 & & 20 & & & \\
\hline Mean & 916.8 & & 950.1 & & & \\
\hline SD & 102.0 & 11.1 & 99.2 & 10.4 & & \\
\hline Median & 920.7 & & 948.4 & & -1.092 & 0.275 \\
\hline
\end{tabular}

n $\quad 50 \quad 20$

Mean $\quad 606.5 \quad 639.4$

$\begin{array}{llll}\text { SD } & 70.5 & 11.6 & 70.8\end{array}$

Median 604.8

628.6

11.1

n $\quad 50 \quad 20$

EDJ junction

Mean $\quad 424.0$

422.1

SD $\quad 40.9$

$9.6 \quad 33.2$

427.8

7.9

Median 420.7

20

Cervical area

$\begin{array}{ll}\mathrm{n} & 46 \\ \text { Mean } & 138.9\end{array}$

SD $\quad 13.4$

Median 135.1

$9.6 \quad 12.1$

12.1

8.4

$\begin{array}{lll}\mathrm{n} & 50 & 19\end{array}$

Enamel/dentin

Mean $\quad 0.51$

SD $\quad 0.05$

0.49

volume ratio

Median $\quad 0.51$

$10.2 \quad 0.05$

9.8

0.49

$-1.599$

0.110

Average enamel thickness

n $\quad 50$

Mean 0.73

SD $\quad 0.05$

Median 0.73

20

20
0.73

$6.8 \quad 0.05$
-

0.74

6.8

$-0.176$

0.860

Average dentin thickness

$\begin{array}{ll}\mathrm{n} & 50 \\ \text { Mean } & 1.43 \\ \mathrm{SD} & .08 \\ \text { Median } & 1.42\end{array}$

$\begin{array}{ll} & 20 \\ & 1.51 \\ 5.6 & 0.08 \\ & 1.51 \\ & \\ & 20 \\ & 2.94 \\ 5.3 & 0.16 \\ & 2.96\end{array}$

5.3

$-3.614$

0.0003

Cervical constriction

$\begin{array}{ll}\mathrm{n} & 46 \\ \text { Mean } & 3.02 \\ \text { SD } & 0.16 \\ \text { Median } & 3.03\end{array}$

20

0.16

5.4

$-1.702$

0.089 
Table 5. Ratios (in bold face) of median dental tissue Primary measures of Sick Pen 'early deaths' or Sick Pen 'late deaths' to Control sample (values for enamel based on only teeth with no or, at most, one cusp with dentine exposure)

\begin{tabular}{|c|c|c|c|c|c|c|c|c|c|}
\hline & \multicolumn{4}{|c|}{ Sick Pen 'early deaths' } & \multicolumn{3}{|c|}{ Sick Pen 'late deaths' } & \multicolumn{2}{|c|}{ Control } \\
\hline & $\underline{\mathrm{N}}$ & $\underline{\text { Median }}$ & $\begin{array}{l}\text { Ratio to } \\
\text { Late deaths }\end{array}$ & $\frac{\text { Ratio to }}{\text { Control }}$ & $\underline{\mathrm{N}}$ & Median & $\frac{\text { Ratio to }}{\text { Control }}$ & $\underline{\mathrm{N}}$ & Median \\
\hline Enamel volume & 36 & $313.1^{1,9}$ & .95 & .94 & 4 & $328.0^{1}$ & .99 & 12 & $332.7^{9}$ \\
\hline EDJ area & 42 & $417.4^{2,10}$ & .93 & .98 & 8 & $450.1^{2}$ & 1.05 & 20 & $427.8^{10}$ \\
\hline Dentin volume & 42 & $597.9^{3,11}$ & .87 & .95 & 8 & $687.5^{3}$ & 1.09 & 20 & $628.6^{11}$ \\
\hline Cervix area & 42 & $134.4^{4,12}$ & .88 & .95 & 8 & $152.8^{4}$ & 1.07 & 20 & $142.2^{12}$ \\
\hline E/D ratio & 36 & $0.53^{5,13}$ & 1.10 & 1.04 & 4 & $0.48^{5}$ & .94 & 19 & $0.51^{13}$ \\
\hline Enam thickness & 36 & $.75^{6,14}$ & 1.03 & .99 & 4 & $0.73^{6}$ & .96 & 20 & $0.76^{14}$ \\
\hline Dentin thickness & 42 & $1.42^{7,15}$ & .97 & .94 & 8 & $1.47^{7}$ & .97 & 20 & $1.51^{15}$ \\
\hline Cerv. constriction & 42 & $3.03^{8,16}$ & 1.01 & 1.02 & 8 & $3.01^{8}$ & 1.02 & 20 & $2.96^{16}$ \\
\hline
\end{tabular}

1. $\mathrm{M}-\mathrm{W} \mathrm{Z}=-0.135, \mathrm{P}=0.892$

2. $\mathrm{M}-\mathrm{W} \mathrm{Z}=-1.773, \mathrm{P}=0.076$

3. $\mathrm{M}-\mathrm{WZ} \mathrm{Z}=-2.143, \mathrm{P}=0.032$

4. $\mathrm{M}-\mathrm{W} \mathrm{Z}=-2.290, \mathrm{P}=0.022$

5. $\mathrm{M}-\mathrm{W} \mathrm{Z}=-2.570, \mathrm{P}=0.006$

6. $\mathrm{M}-\mathrm{WZ} \mathrm{Z}=-1.610, \mathrm{P}=0.107$

7. $\mathrm{M}-\mathrm{W} \mathrm{Z}=-1.799, \mathrm{P}=0.072$

8. $\mathrm{M}-\mathrm{W} Z=-0.725, \mathrm{P}=0.469$

9. $\mathrm{M}-\mathrm{W} \mathrm{Z}=-0.279, \mathrm{P}=0.781$

10. $M-W Z=-0.685, P=0.493$

11. $\mathrm{M}-\mathrm{W} Z=-2.108, \mathrm{P}=0.035$

12. $\mathrm{M}-\mathrm{W} Z=-1.890, \mathrm{P}=0.059$

13. $\mathrm{M}-\mathrm{W} Z=-2.134, \mathrm{P}=0.033$

14. $\mathrm{M}-\mathrm{W} Z=-0.143, \mathrm{P}=0.886$

15. $M-W Z=-3.975, P=0.0001$

16. $M-W Z=-1.750, P=0.080$ 
Table 6. Comparison of dental tissue measurements (median test) among all six developmental cohorts ranging from theoretical worst to best outcome.

\begin{tabular}{|c|c|c|c|c|c|c|c|c|c|}
\hline \multirow[t]{3}{*}{ Measure } & & \multicolumn{4}{|c|}{ Sick Pen 'early deaths' } & 'Late deaths' & Control & \multicolumn{2}{|l|}{ Median test } \\
\hline & & \multicolumn{6}{|c|}{ Developmental outcomes from theoretical worst (1) to best (6) } & & \\
\hline & & $\underline{1}$ & $\underline{2}$ & $\underline{3}$ & $\underline{4}$ & $\underline{5}$ & $\underline{6}$ & $\underline{\text { Chi square }}$ & $\underline{\text { Prob. }}$ \\
\hline \multirow{4}{*}{$\begin{array}{l}\text { Enamel cap } \\
\text { volume }\end{array}$} & $\mathrm{N}$ & 14 & 12 & 11 & 5 & 8 & 20 & & \\
\hline & Mean & 335.8 & 298.9 & 298.6 & 286.8 & 313.6 & 310.7 & & \\
\hline & SD & 36.7 & 33.5 & 25.4 & 35.2 & 52.7 & 37.9 & & \\
\hline & Median & 329.2 & 298.2 & 291.6 & 275.7 & 328.0 & 307.0 & 11.794 & 0.038 \\
\hline \multirow{4}{*}{$\begin{array}{l}\text { Coronal dentin } \\
\text { volume }\end{array}$} & $\mathrm{N}$ & 14 & 12 & 11 & 5 & 8 & 20 & & \\
\hline & Mean & 608.9 & 578.3 & 586.8 & 617.1 & 665.0 & 639.4 & & \\
\hline & SD & 67.7 & 66.7 & 50.5 & 62.2 & 86.4 & 70.8 & & \\
\hline & Median & 610.3 & 568.7 & 610.7 & 581.6 & 687.5 & 628.6 & 6.091 & 0.297 \\
\hline \multirow{4}{*}{$\begin{array}{l}\text { EDJ junction } \\
\text { surface area }\end{array}$} & $\mathrm{N}$ & 14 & 12 & 11 & 5 & 8 & 20 & & \\
\hline & Mean & 440.5 & 410.0 & 406.0 & 416.0 & 445.7 & 422.1 & & \\
\hline & SD & 46.6 & 36.1 & 28.4 & 40.8 & 39.1 & 33.2 & & \\
\hline & Median & 438.0 & 404.4 & 413.0 & 403.9 & 450.1 & 628.6 & 12.959 & 0.024 \\
\hline \multirow[t]{4}{*}{ Cervical area } & $\mathrm{N}$ & 10 & 12 & 11 & 5 & 8 & 20 & & \\
\hline & Mean & 137.5 & 133.6 & 137.8 & 139.7 & 149.6 & 143.7 & & \\
\hline & SD & 16.8 & 12.2 & 8.8 & 11.4 & 13.4 & 12.1 & & \\
\hline & Median & 133.6 & 132.7 & 138.2 & 135.3 & 152.8 & 142.2 & 11.191 & 0.048 \\
\hline \multirow{4}{*}{$\begin{array}{l}\text { Enamel/dentin } \\
\text { volume ratio }\end{array}$} & $\mathrm{N}$ & 14 & 12 & 11 & 5 & 8 & 19 & & \\
\hline & Mean & 0.55 & 0.52 & 0.51 & 0.47 & 0.47 & 0.49 & & \\
\hline & SD & 0.04 & 0.04 & 0.02 & 0.04 & 0.03 & 0.05 & & \\
\hline & Median & 0.55 & 0.53 & 0.51 & 0.48 & 0.47 & 0.49 & 22.516 & .0004 \\
\hline \multirow{4}{*}{$\begin{array}{l}\text { Average enamel } \\
\text { thickness }\end{array}$} & $\mathrm{N}$ & 14 & 12 & 11 & 5 & 8 & 20 & & \\
\hline & Mean & 0.76 & 0.73 & 0.74 & 0.69 & 0.70 & 0.73 & & \\
\hline & SD & 0.04 & 0.05 & 0.04 & 0.04 & 0.07 & 0.05 & & \\
\hline & Median & 0.76 & 0.73 & 0.73 & 0.71 & 0.73 & 0.74 & 12.574 & 0.028 \\
\hline \multirow{4}{*}{$\begin{array}{l}\text { Average dentin } \\
\text { thickness }\end{array}$} & $\mathrm{N}$ & 14 & 12 & 11 & 5 & 8 & 20 & & \\
\hline & Mean & 1.38 & 1.41 & 1.44 & 1.48 & 1.49 & 1.51 & & \\
\hline & SD & 0.07 & 0.06 & 0.05 & 0.04 & 0.10 & 0.08 & & \\
\hline & Median & 1.38 & 1.40 & 1.44 & 1.47 & 1.47 & 1.51 & 17.534 & 0.004 \\
\hline \multirow{4}{*}{$\begin{array}{l}\text { Cervical } \\
\text { constriction }\end{array}$} & $\mathrm{N}$ & 10 & 12 & 11 & 5 & 8 & 20 & & \\
\hline & Mean & 3.10 & 3.07 & 2.95 & 2.97 & 2.99 & 2.94 & & \\
\hline & SD & 0.13 & 0.17 & 0.18 & 0.09 & 0.17 & 0.16 & & \\
\hline & Median & 3.15 & 3.15 & 2.91 & 2.99 & 3.01 & 2.96 & 11.473 & 0.043 \\
\hline
\end{tabular}




\section{Table 7. Evaluation (median tests) of heterogeneity within the Sick Pen 'early deaths' group}

Measure

Enamel cap
volume
Coronal dentin
volume
EDJ junction
surface area
Cervical
area
Enamel/dentin
volume ratio
Average enamel
thickness
Average dentin
thickness
Cervical
constriction

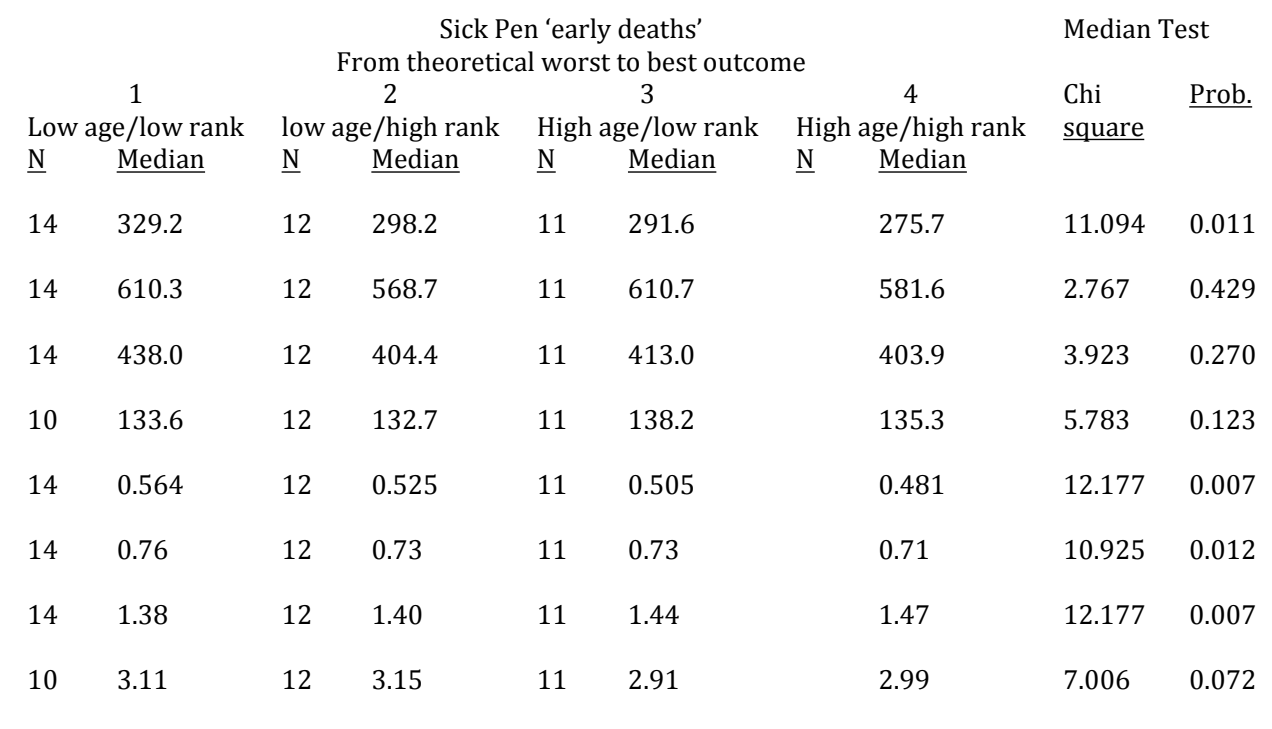


Table 8. Tissue mass compared among pigs with no hard tissue lesions, pigs with disturbed growth of the mandibular rami, and pigs with well-established bone or soft tissue lesions (thought to have formed during crown formation) (statistically significant differences in bold).

\begin{tabular}{|c|c|c|c|c|c|c|c|c|}
\hline & & & & & & & Kruskal W & lis \\
\hline & Measure & Pathology & $\underline{\mathrm{N}}$ & Mean & $\underline{S D}$ & Median & Chi square & Prob \\
\hline Unworn & Enamel & No lesions & 4 & 323.3 & 18.5 & 317.8 & 0.970 & 0.616 \\
\hline Enamel $^{1}$ & volume & Bone formation & 20 & 320.1 & 37.0 & 318.0 & & \\
\hline & & Infections & 9 & 305.1 & 39.2 & 314.7 & & \\
\hline Unworn & Enamel & No lesions & 21 & 307.2 & 33.6 & 308.6 & 3.604 & 0.165 \\
\hline and worn & volume & Bone formation & 37 & 317.0 & 41.0 & 319.8 & & \\
\hline & & Infections & 12 & 295.9 & 37.5 & 274.9 & & \\
\hline & EDJ area & No lesions & 21 & 422.3 & 34.5 & 426.0 & 7.318 & 0.026 \\
\hline & & Bone formation & 37 & 432.3 & 39.6 & 428.6 & & \\
\hline & & Infections & 12 & 398.1 & 32.9 & 389.9 & & \\
\hline & Dentin & No lesions & 21 & 624.5 & 68.7 & 602.6 & 6.837 & 0.033 \\
\hline & volume & Bone formation & 37 & 626.9 & 72.7 & 620.2 & & \\
\hline & & Infections & 12 & 566.6 & 55.7 & 562.1 & & \\
\hline & Cervix & No lesions & 21 & 143.2 & 12.8 & 141.5 & 4.899 & 0.086 \\
\hline & area & Bone formation & 34 & 141.1 & 13.7 & 142.2 & & \\
\hline & & Infections & 11 & 132.5 & 8.9 & 132.1 & & \\
\hline
\end{tabular}

1. includes teeth with 'trace' enamel wear; i.e., faceting 
Table 9. Dental tissue masses compared between pigs with and without wellestablished hard tissue lesions judged to be of infectious origin (statistically significant differences in bold).

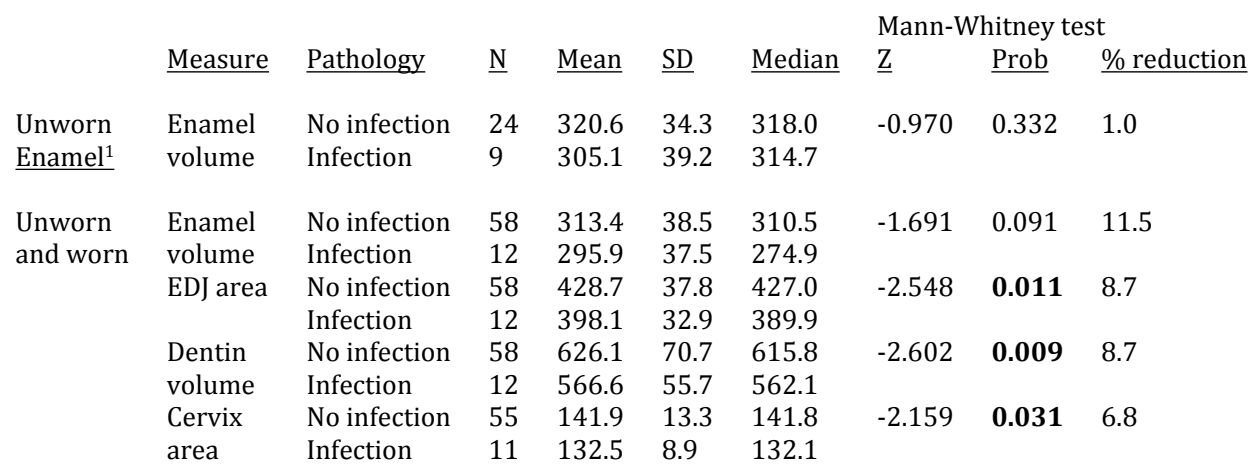

1. includes teeth with 'trace' enamel faceting 
Figure 1. Organization and terms for analysis of dental measures of mortality cohort sub-groups. Sick pen pigs died naturally and are termed the Attritional assemblage. Control pigs are those that survived to slaughter age and are termed the Catastrophic assemblage. The term 'rank' refers to relative physiological maturity based on combined measures of dental formation, skull length and weight at death (see text for further details). Note that some Sick pen pigs survived for a while beyond normal age for slaughter; these are considered 'late deaths'.

$152 \times 114 \mathrm{~mm}(300 \times 300 \mathrm{DPI})$ 


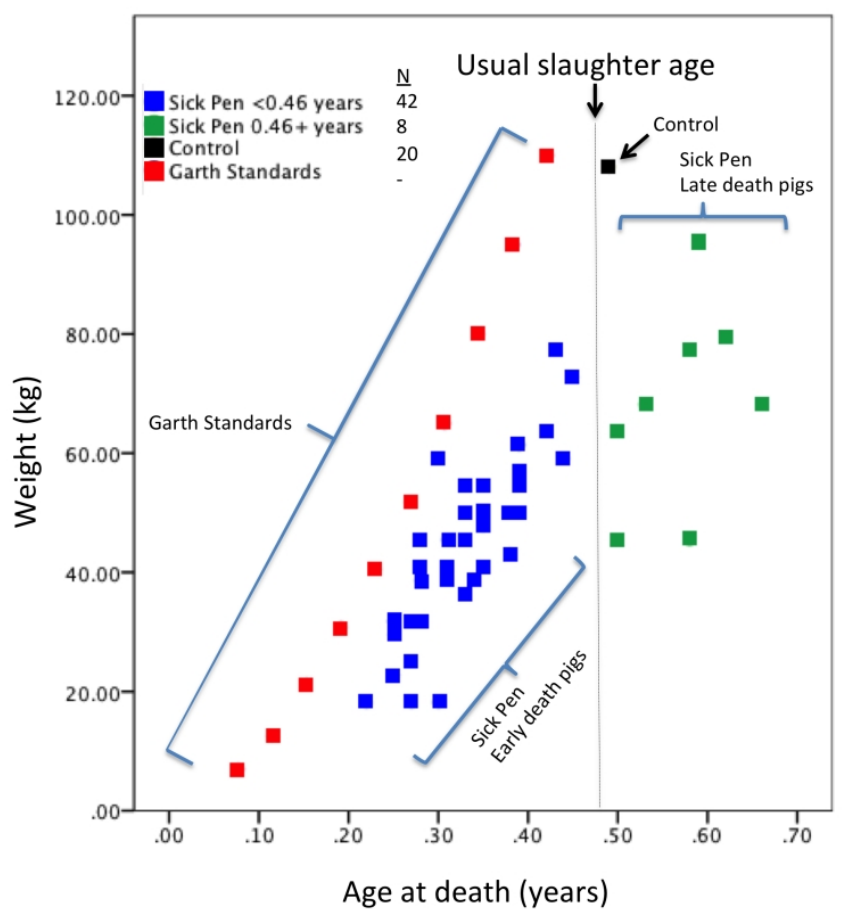

Figure 2. Relationship of body weight at death and age at death among Sick Pen 'early death' pigs, Sick Pen 'late death' pigs, and Control pigs compared to a standard. Pigs are slaughtered for consumption at a typical age (180 days) and weight (108 kg). Note that all Sick Pen pigs are light for age; and 'late deaths' clearly form a separate cluster.

$1057 \times 793 \mathrm{~mm}(72 \times 72 \mathrm{DPI})$ 
Figure 3. Relationship of Developmental Rank (average seriated maturity markers: dental formation, skull length, and body weight) to age at death. Control animals are not included as their individual weights and age at death are unknown. The distinctiveness of the Sick Pen 'late deaths' is accentuated here; they are developmentally retarded for their ages.

\section{$1057 \times 793 \mathrm{~mm}(72 \times 72$ DPI $)$}



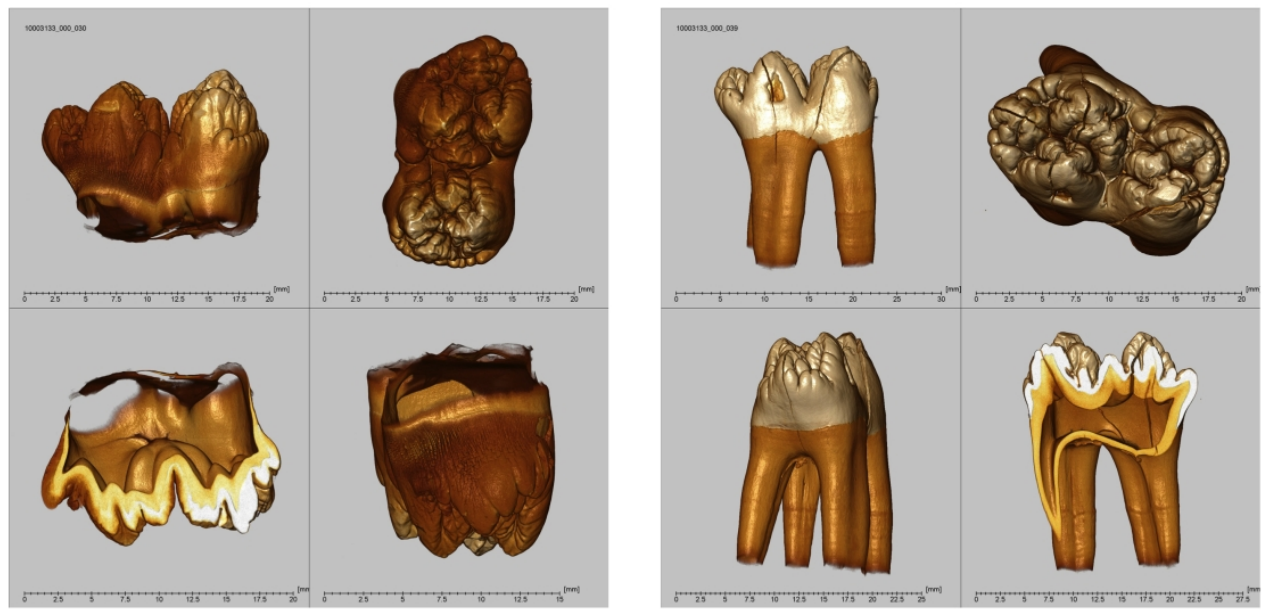

Figure 4. Screenshots of the youngest and oldest pig lower first molars in our study; Sick Pen pig 30 (aged 0.22 years, right molar crown complete but not fully mineralized) and 39 (aged 0.66 years, a 'late death' pig left molar crown), respectively.

$1057 \times 793 \mathrm{~mm}(72 \times 72 \mathrm{DPI})$ 
Figure 5. Enamel cap volume: comparison of median values among cohorts ranged from theoretical worst to best developmental outcome. Probability value indicates whether differences in medians are statistically significant (alpha is 0.05). Significant pairwise post hoc differences are shown. Lower panel shows heterogeneity of the Sick Pen assemblage by graphing the relationship of dental measure to survivorship among just the Sick Pen 'early deaths' in comparison to the 'late deaths' cohort whose median age and tissue measure value are indicated by the black square. Progressively older Sick Pen 'early death' pigs show diminishing volumes with age at death while the Sick Pen 'late deaths' show even larger values than the Controls.

$1057 \times 793 \mathrm{~mm}(72 \times 72$ DPI $)$ 
Figure 6. Coronal dentin mass compared among developmental outcome cohorts (as for Figure 5). There are no significant differences overall although large size of the Sick Pen 'late deaths' coronal dentin is evident.

1057x793mm (72 x 72 DPI) 
Figure 7. Surface area of the enamel-dentin junction compared among developmental outcome cohorts (as for Figure 4). Overall, median values differ significantly, which is driven by a decline in surface area among the SP 'early death' cohorts. Large size of the 'late deaths' cohort is noteworthy as is the similarity of the pattern of this variable to that of enamel (Fig. 5) rather than dentin (Fig. 6).

$1057 \times 793 \mathrm{~mm}(72 \times 72 \mathrm{DPI})$ 

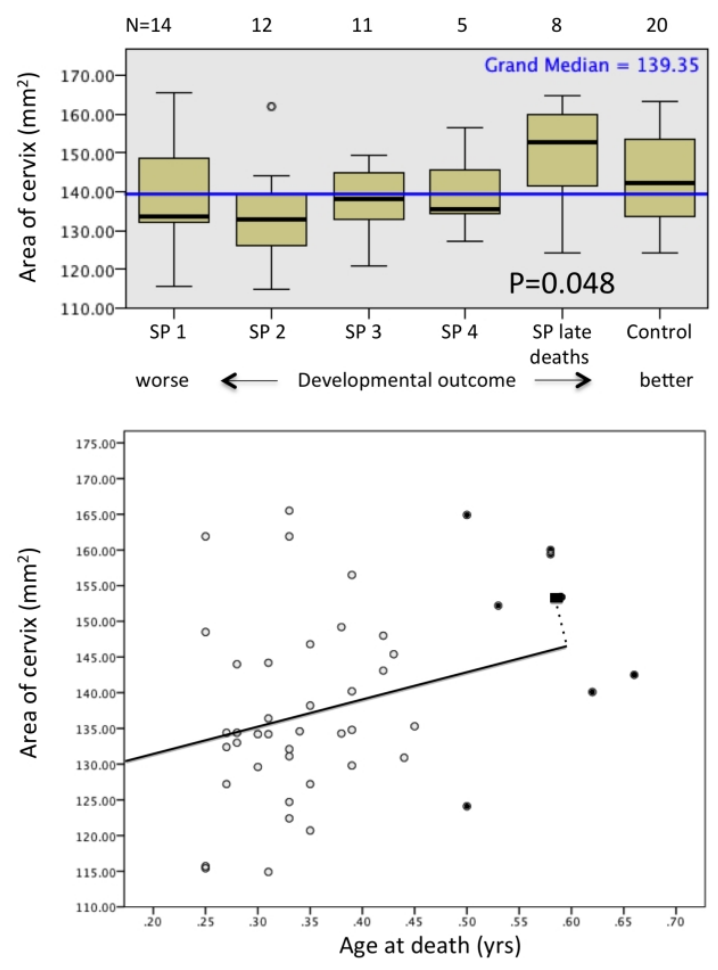

Figure 8. Area of the cervix compared among developmental outcome cohorts (as for Figure 5). There is a statistically significant difference among medians, which seems to be driven by the comparatively small cervices of the SP 'early death' cohorts.

$1057 \times 793 \mathrm{~mm}(72 \times 72 \mathrm{DPI})$ 

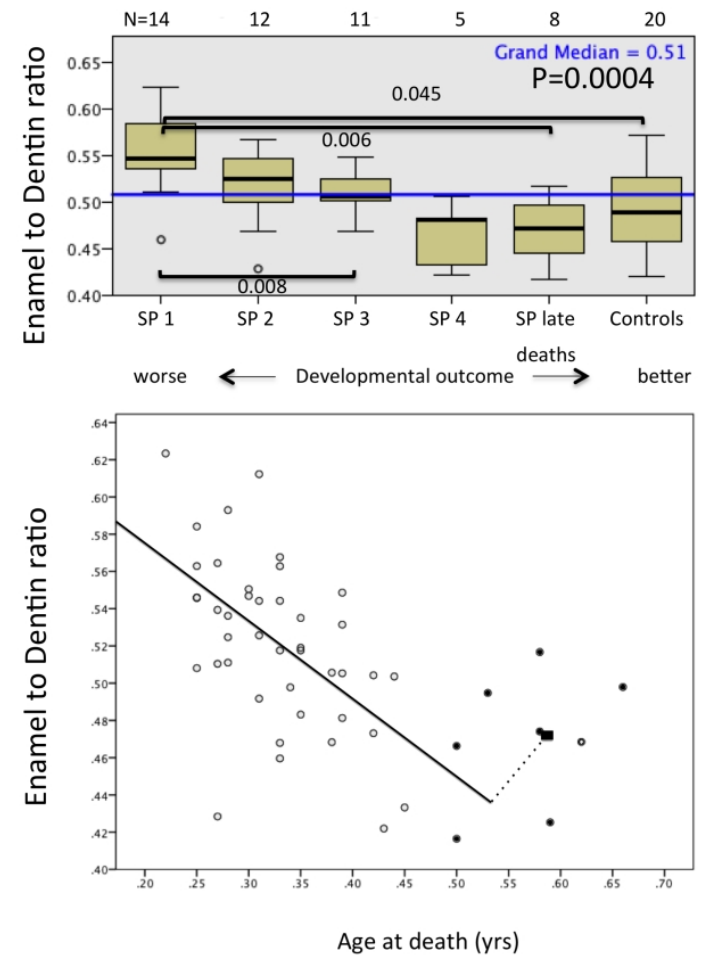

Figure 9. Ratio of enamel volume to that of dentin compared among developmental outcome cohorts (as for Figure 5). The strong statistical trend is a function of slightly increasing dentine volume combined with significantly decreasing enamel volume with increasing age at death in the Sick Pen 'early death' cohorts.

$1057 \times 793 \mathrm{~mm}(72 \times 72 \mathrm{DPI})$ 

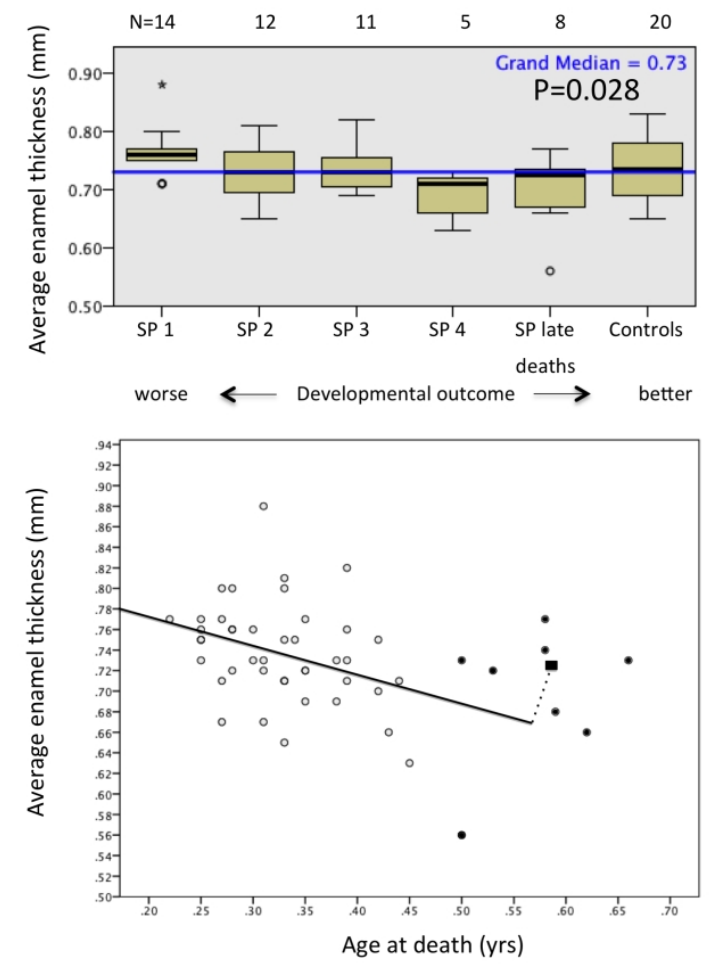

Figure 10. Average enamel thickness compared among developmental outcome cohorts (as for Figure 5). The behavior of this variable is a function of relative volume and surface area of the EDJ. The decline in enamel thickness shown among the Sick Pen 'early deaths' cohorts in the bottom panel, while statistically significant, reflects simply enamel cap volume reduction in this group.

$1057 \times 793 \mathrm{~mm}(72 \times 72 \mathrm{DPI})$ 
Figure 11. Average dentin thickness compared among developmental outcome cohorts (as for Figure 5). The behavior of this variable is a function of relative volume and surface area of the EDJ. Dentin is progressively thicker in longer-surviving cohorts.

$1057 \times 793 \mathrm{~mm}(72 \times 72 \mathrm{DPI})$ 
Figure 12. Cervical constriction (EDJ area/Cervix area) compared among developmental outcome cohorts (as for Figure 5). There is a statistically significant difference overall among medians driven by a tendency for shorter-lived pigs to have more constricted cervices.

$1057 \times 793 \mathrm{~mm}(72 \times 72$ DPI $)$ 


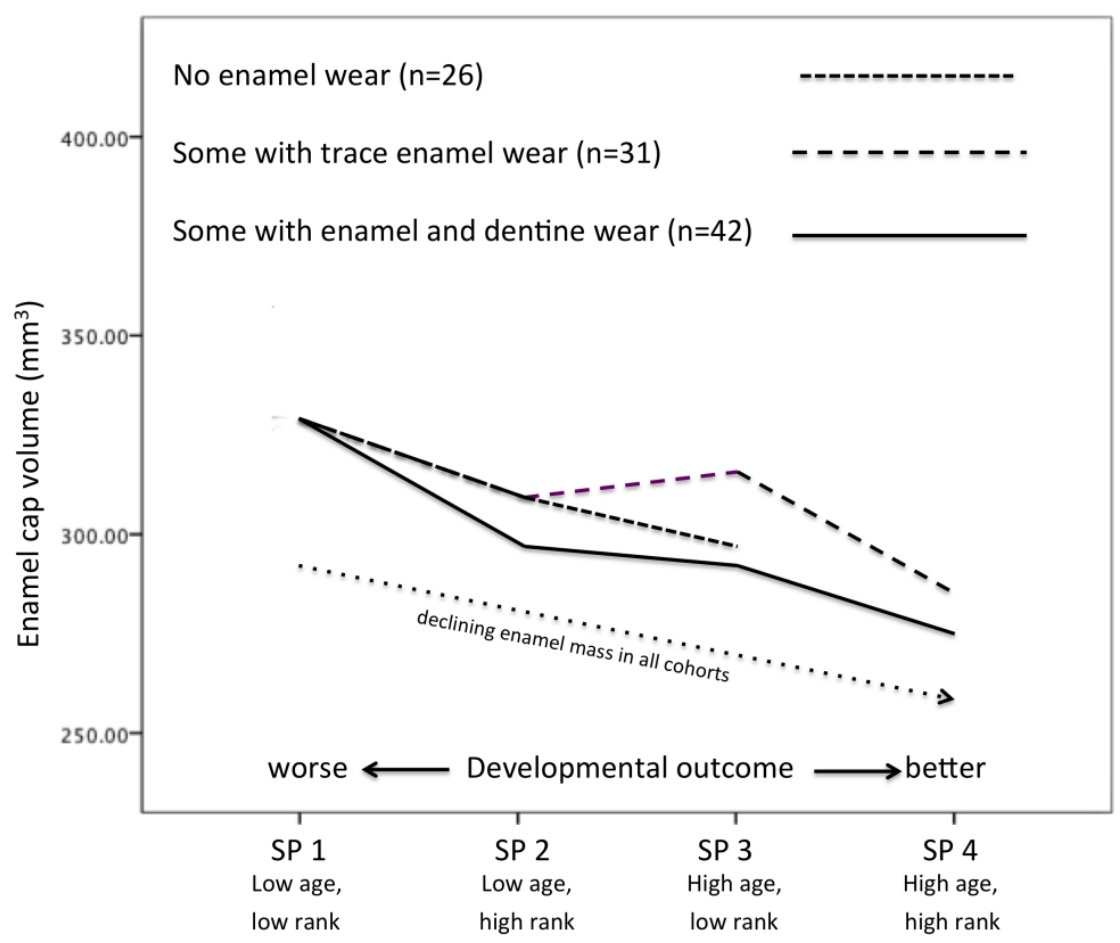

Figure 13. Enamel cap volume compared among Sick Pen 'early death' cohorts illustrating the decline in enamel volume with increasing developmental rank regardless of the potential impact of occlusal wear on this variable.

$1057 \times 793 \mathrm{~mm}(72 \times 72 \mathrm{DPI})$ 


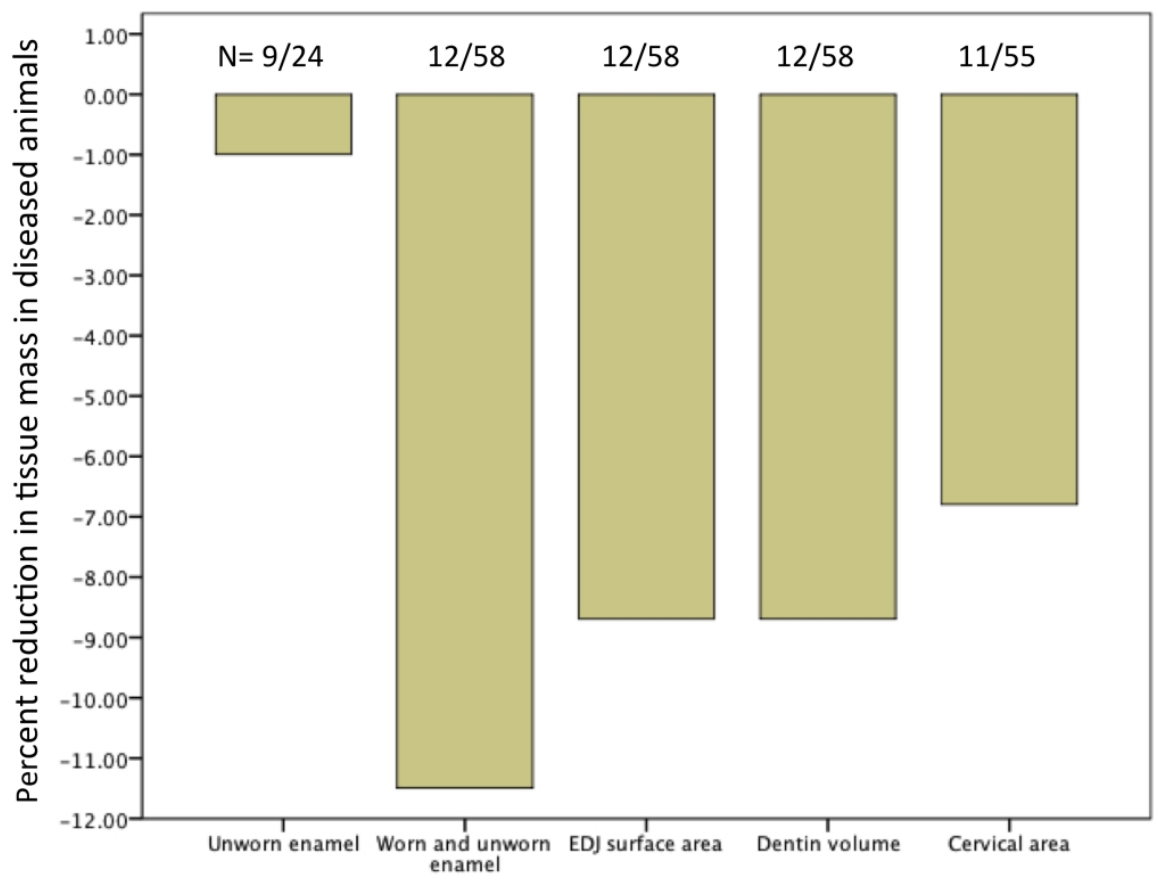

Figure 14. Percent decrement in tissue measure compared between animals with and without wellestablished hard tissue lesions. Sample sizes are shown for affected and unaffected animals. All coronal measures are reduced in animals with chronic disease.

$1057 \times 793 \mathrm{~mm}(72 \times 72 \mathrm{DPI})$ 


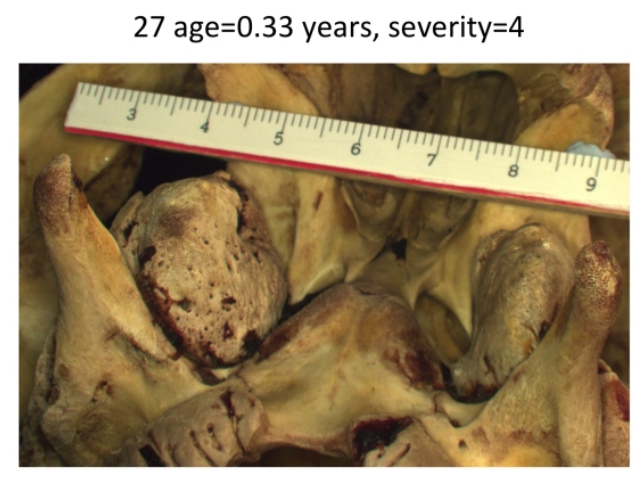

47 age $=0.34$ years, severity $=6$

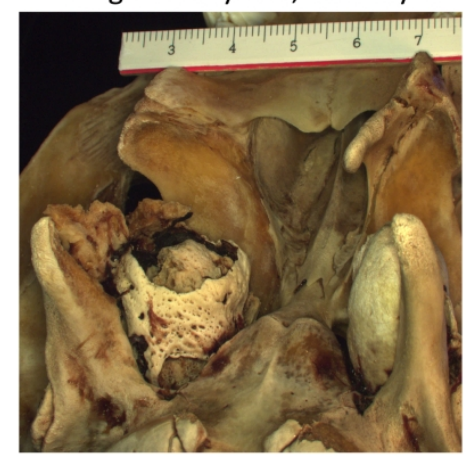

34 age $=0.30$ years, severity $=6$

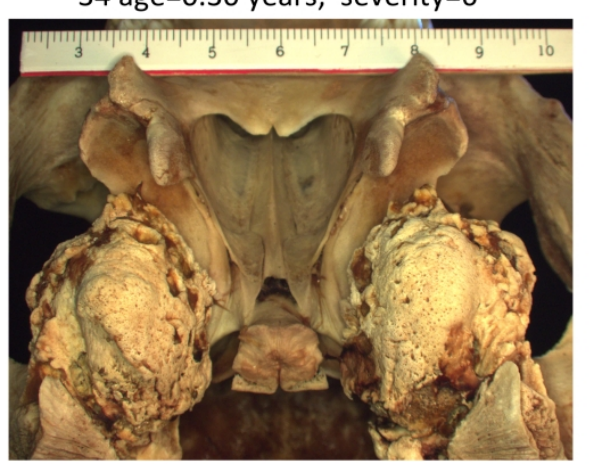

Figure 15. Examples of abnormal remodeling of auditory bullae. Severity score 6 is the most severe. Note shell formation in Pig 47 and lack of involvement of its left bulla. Note Pig 34 with very severe bilateral involvement and its early age at death (Fig. 16).

1057×793mm (72 x 72 DPI) 


\section{1}

2

3

4

5

6

7

8

9

10

11

12

13

14

15

16

17

18

19

20

21

22

23

24

25

26

27

28

29

30

31

32

33

34

35

36

37

38

39

40

41

42

43

44

45

46

47

48

49

50

51

52

53

54

55

56

57

58

59

60
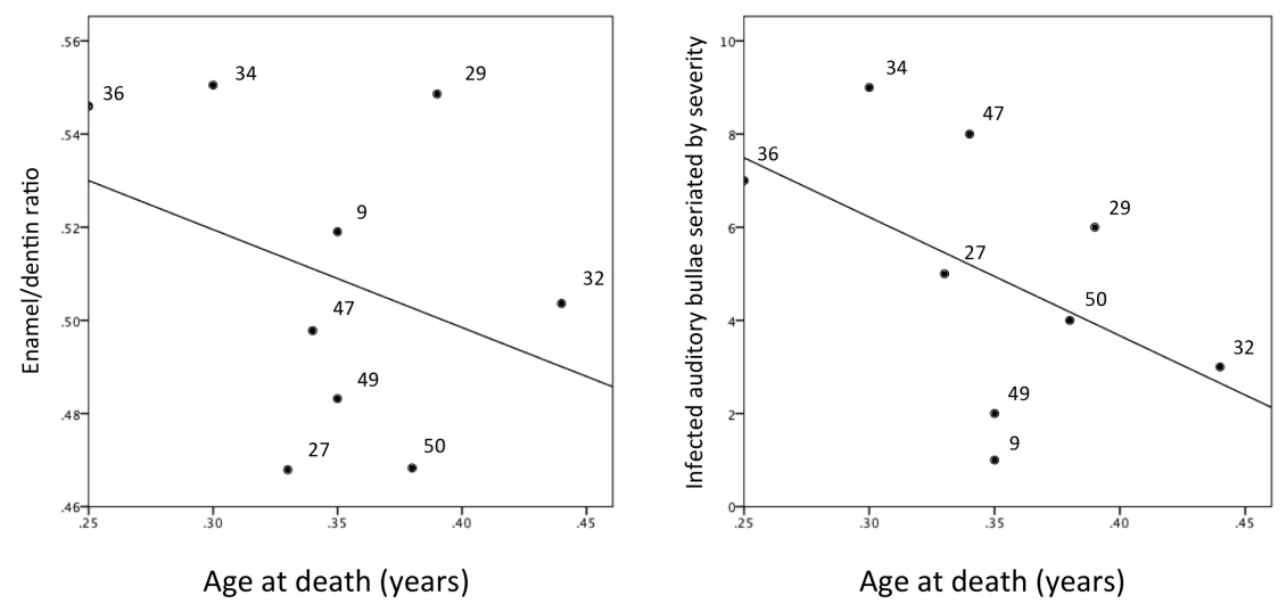

Figure 16. Relationship of enamel/dentin ratio to age at death in those pigs with abnormal auditory bullae. Note that enamel and coronal dentin formation are completed before death, implying that the disease probably existed before crown completion. Both severity of bone remodeling and enamel thickness decline with increasing survivorship.

$1057 \times 793 \mathrm{~mm}(72 \times 72$ DPI $)$ 